\title{
Pengaruh Modernisasi di Turki terhadap Penafsiran Bediuzzaman Said Nursi
}

\section{Labib Syauqi Akifahadi}

Pusat Kajian Kawasan Asia Timur (PUKKAT) UIN Syarif Hidayatullah Jakarta labib_syauqi@yahoo.com

\begin{abstract}
This paper describes the influence of modernization that occurred in Turkey on the interpretation of Said Nursi, who focused on the three important points, i.e. the interpretation on science and technology, the relation of religion and state, and on gender relations. First, science has a neutral nature, because it needs to be appreciated, whether it comes from Islam or from the West. Second, nationalism manifested in the form of blind secularization or excessive Westernization is wrong.
\end{abstract}

Keywords: Renewal of Turkey, science and technology, religion and state, gender.

\begin{abstract}
Abstrak: Tulisan ini menjelaskan pengaruh modernisasi yang terjadi di Turki terhadap penafsiran Said Nursi, yang dikhususkan dalam tiga poin penting, yaitu penafsiran Nursi terhadap ilmu pengetahuan dan teknologi, tentang hubungan agama dan negara, dan tentang relasi jender. Pertama, bagi Nursi, ilmu pengetahuan memunyai sifat yang netral, karena itu perlu diapresiasi, entah datangnya dari Islam atau dari Barat. Kedua, nasionalisme yang diwujudkan dalam bentuk sekularisasi buta atau Westernisasi kebablasan adalah salah. Ketiga, persamaan hak dan relasi jender laki-laki dengan perempuan, harus diwujudkan dengan tujuan untuk saling menyempurnakan kekurangan masing-masing supaya terwujud suatu kehidupan yang harmonis dan dinamis.
\end{abstract}

Kata Kunci: Pembaruan Turki, sains dan teknologi, agama dan negara, jender. 


\section{Pendahuluan}

Nilai suatu penafsiran adalah sesuatu yang profan bagi manusia dan bersifat relatif, bukanlah bernilai sakral yang wajib diikuti dan mengandung kebenaran mutlak. Upaya penafsiran yang dilakukan oleh seorang mufassir adalah tidak lepas dari konteks ruang sosialnya, karena proses penafsiran yang dilakukan mufassir tidaklah dilakukan pada ruang hampa yang terlepas dari kehidupan sosialnya. Hal ini tidak lepas dari pergumulan seorang penafsir dengan lingkungan sosial, budaya, politik, dan agama yang ada di sekelilingnya. Sebuah karya tafsir merupakan sebuah produk sosial dan karya manusia biasa, yang tidak pantas dianggap sakral dan juga tidak kebal akan kritikan.

Aksi para pembaharu Islam terhadap gejala datangnya modernisasi ${ }^{1}$ yang mendunia meniscayakan adanya perbedaan reaksi prinsipil menurut perbedaan konteks sosial hitoris. Hal tersebut dikarenakan mereka pasti tidak akan terlepas dengan konteks sosio historis yang berkembang di mana mereka berada ${ }^{2}$, karena seseorang merupakan produk dari zamannya. Ketika menyebutkan keterpengaruhan penafsiran terhadap kondisi lokal, maka hal yang muncul berikutnya adalah pandangan-pandangan baru yang muncul tentang kontekstualitas al-Qur'ān sebagai respon terhadap pertanyaan-pertanyaan baru yang muncul dari perubahan-perubahan politik, sosial dan kultural dalam masyarakat-masyarakat Muslim yang disebabkan oleh pengaruh peradaban Barat.

Merespon isu modernitas ketika dihadapkan dengan Islam, tradisi dan juga Westernisasi, salah seorang pemikir Muslim abad 20 yang berasal dari Turki bernama Bediuzzaman Said Nursi, banyak menanggapi permasalahan tersebut dengan konsep modernitas yang dimilikinya, banyak isu-isu modern yang ditanggapinya dalam karyakaryanya. Said Nursi lahir pada tahun $1876^{3}$ dan wafat pada 1960. Selama masa hidupnya, Said Nursi banyak menyaksikan peristiwa penting dalam sejarah Islam dan khususnya Turki, mulai dari rapuhnya kerajaan Islam terakhir hingga jatuh dan berubahnya Turki 'Utsmānī menjadi republik sekular.

Ibrahim M. Abū Rabi' dalam pengantar buku karya Vahide mengatakan bahwa, Nursi tampil sebagai seorang ulama dengan visi yang kuat untuk menyatukan dunia Islam yang mulai terpecah. 
Kehidupan Nursi adalah sebuah narasi sejarah yang melambangkan kehidupan, bukan hanya kehidupan bangsa Turki, melainkan kehidupan seluruh umat Islam di zaman modern. Sepak terjang dan karya-karya Nursi memberikan wawasan luas dan gambaran yang mendalam tetang masa sejarah pasca Tanzimat di Turki, keadaan sulit yang dialami ulama tradisional, kegagalan gerakan reformasi Islam pada abad ke-19 untuk memberikan sebuah solusi Islami dalam menghadapi ancaman Westernisasi, landasan falsafat dan politik munculnya nasionalisme sekuler di Turki, penghapusan kekhalifahan 'Utsmānī pada tahun 1924, dan nasib agama di Turki pada masa pemerintahan Kemal Attaturk. ${ }^{4}$

Karya Bediuzzaman Said Nursi yang menjadi masterpiece atas karya-karyanya adalah Risālah al-Nür. Dalam kitab ini, Nursi banyak menyinggung tentang moralitas yang merupakan platform pemikiran Nursi, karena Nursi hidup ketika materialisme dan komunisme sedang menggelora dengan dekadensi moral yang melanda dunia, sedangkan di sisi lain ilmu pengetahuan dan teknologi sedang menemukan surganya. ${ }^{5}$

Di samping masalah moral yang banyak dibahas, pokok tema dalam penafsiran Nursi juga banyak merespon isu relevansi negara Islam apakah masih patut diperjuangkan sebagai dasar negara atau tidak, ${ }^{6}$ dan juga banyak pembahasan tentang hubungan antara Islam dengan modernitas. ${ }^{7}$ Di samping juga yang tidak kalah pentingnya, bahwa masalah keadilan dan persamaan hak antara laki-laki dan perempuan juga menjadi pembahasan yang mendapat perhatian Nursi, terbukti bahwa ia memunyai risalah khusus tentang perempuan. Jadi Nursi dalam karya-karyanya, banyak menanggapi isu-isu modern yang berkembang dan tidak bisa dilepaskan dari sejarah dan modernisasi Turki pada waktu itu yang sedang melanda; mulai dari moralitas, keimanan, ilmu pengetahuan dan teknologi, falsafat, hingga masalah persamaan hak antara laki-laki dan perempuan.

Penulis membatasi pembahasan tulisan ini pada bagaimana pegaruh modernisasi yang terjadi di Turki terhadap penafsiran Said Nursi, yang kemudian dikhususkan dalam tiga poin pembahasan penting, yaitu penafsiran Nursi terhadap ilmu pengetahuan dan teknologi, tentang hubungan agama dan negara, dan juga tentang 
perempuan dan persamaan hak. Sesuai dengan pembatasan masalah yang telah ditentukan di atas, maka permasalahan tulisan ini dapat dirumuskan dalam bentuk pertanyaan sebagai berikut: "Apa pengaruh modernisasi di Turki terhadap penafsiran Bediuzzaman Said Nursi?”

Setelah penulis melakukan penelusuran, penulis menemukan beberapa karya ilmiah baik berupa buku maupun tulisan yang terkait dengan pembahasan Said Nursi, Buku yang ditulis Şükran Vahide ${ }^{8}$ dan Ihsan Kasim Salih' lebih fokus dan panjang lebar menjelaskan tentang biografi intelektual Said Nursi dan perjuangannya semasa hidupnya. Dalam bentuk tulisan terdapat karya Muhammad Adlan yang berjudul, "Metode Penafsiran al-Qur'ān Said Nursi dalam Risālah al-Nür". ${ }^{10}$ Dalam tulisan ini dibahas tentang metode penafsiran Said Nursi dalam Risälah al-Nür. Dalam tulisan lain terdapat karya Iis Ishak Sholih dengan judul "Nasionalisme Islam: Pemikiran Politik Said Nursi". ${ }^{11}$ Tulisan ini membahas tentang konsep-konsep Nursi tentang nasionalisme dalam Islam dan bagaimana seharusnya memahami nasionalisme menurut Nursi.

Ada juga dalam bentuk tesis karya Hasbi Sen yang berjudul "Prinsip-prinsip Politik Islam Menurut Bediuzzaman Said Nursi". ${ }^{12}$ Tesis ini memaparkan bagaimana prinsip-prinsip berpolitik dalam Islam menurut perspektif Said Nursi, bagaimana seharusnya sikap dan posisi orang Islam dalam berpolitik. Dalam bentuk tesis yang lain terdapat karya Afriyantoni yang berjudul "Prinsip-prinsip Pendidikan Akhlak Generasi Muda Menurut Bediuzzaman Said Nursi”. ${ }^{13}$ Tesis ini menjelaskan panjang lebar tentang suatu komitmen yang mendalam mengenai kehidupan menuju arah terciptanya perilaku lahir dan batin yang seimbang (seperti Nabi) bagi generasi muda menurut pemahaman Bediuzzaman Said Nursi.

Di antara karya-karya yang telah ada, belum ditemukan adanya karya yang mencoba menelusuri dengan serius tentang keterpengaruhan penafsiran Bediuzzaman Said Nursi oleh modernisasi yang ada di Turki.

\section{Riwayat Hidup dan Karier Intelektual Bediuzzaman Said Nursi}

Said Nursi lahir menjelang fajar terbit pada $1293 \mathrm{H} . / 1876 \mathrm{M} . .^{14}$, di sebuah desa bernama Nurs, salah satu perkampungan di wilayah 
Bitlis $^{15}$ yang terletak di wilayah timur Anatolia. Dia dilahirkan dalam sebuah keluarga petani yang sederhana. Ayahnya bernama Mirza, seorang sufi besar yang sangat $\operatorname{war}_{\vec{a}}{ }^{16}$ dan diteladani sebagai seorang yang tidak pernah memakan barang haram dan hanya memberi makan anak-anaknya dengan makanan yang halal saja. Sedangkan ibunya bernama Nūrīyah yang menurut pengakuannya hanya menyusui anak-anaknya dalam keadaan suci dan berwudu. keluarganya tergolong dalam keluarga atau suku Kurdi. Said Nursi sendiri adalah anak keempat dari tujuh bersaudara.

Said Nursi pertama kali mengenyam pendidikan formalnya di bangku madrasah pimpinan Muhammad Affandi di desa Thag. Di samping itu, ia juga belajar informal pada kakanya Abdullah. Dia belajar di Thag tidak berlangsung lama, hanya sebentar saja karena kegiatan belajarnya kemudian dilanjutkan di madrasah desa Birmis. Pada tahun 1888 M. ia pergi ke Bitlis dan mendaftarkan diri di sekolah Syaikh Amin Affandi, itu pun tak berlangsung lama sebab Syaikh tersebut enggan mengajarnya dengan alasan usia yang belum memadai. Hal ini sempat membuatnya bersedih. Akan tetapi kemudian ia mengalihkan perhatiannya untuk masuk ke sekolah Mir Hasan Wali di Muskus, kemudian di sekolah yang terletak Waston, dan hanya bertahan satu bulan. Kemudian ia melanjutkan sekolahnya di Bayazid, ${ }^{17}$ sebuah sekolah yang di sanalah dia kemudian belajar disiplin ilmu-ilmu agama dasar.

Pada tahun 1889, Said Nursi berangkat menuju Bitlis untuk berguru pada Syaikh Muhammad Amin. Dan setelah dari sini ia melanjutkan perjalanan intelektualnya menuju Syirwan dan kemudian menuju Si'rad untuk belajar pada seorang ulama kenamaan yang bernama Fathullah Afandi. Dan ketika Said Nursi berada di bawah bimbingan Syaikh Fathullah Afandi, beliau secara intensif dalam jangka waktu satu minggu mampu membaca dan menghafalkan kitab Jam' al-Jawāmi' karya Ibn al-Subkī. ${ }^{18}$

Tahun 1892 M. Said Nursi berangkat ke Mardin untuk menyampaikan pengajian di Masjid Raya dan dalam acara tanya jawab dengan penduduk setempat. Walikota setempat, Nadir Bek mendengar hal tersebut. Dan karena terkena hasutan orang-orang yang tidak senang dengan Nursi, ia merasa bahwa Said Nursi 
adalah seseorang yang berbahaya dan perlu diwaspadai. Dengan adanya peristiwa tersebut, ia dideportasi untuk kembali ke kota Bitlis lagi. ${ }^{19}$ Lain hal dari walikota Mardin yang mengusirnya dan mendeportasinya, walikota Bitlis justru sangat memuliakan Said Nursi dengan memintanya untuk tinggal di rumahnya, meskipun permintaan itu sempat ditolak berkali-kali oleh Said Nursi. Selama berada di rumah walikota Bitlis, Said Nursi banyak menelaah dan menghafalkan kitab-kitab pokok tentang ilmu-ilmu keislaman.

Terakhir kali Said Nursi diajar oleh seseorang adalah ketika dia berada di Bitlis. Pelajaran itu berasal dari seorang tokoh terkemuka di sana, yaitu Syaikh Muhammad Kufrevi. Said Nursi memiliki cinta yang amat besar kepada syaikh-syaikh yang hebat dari Anatolia Timur. Empat di antara para Syaikh ini disebutkan di dalam biografinya. Mereka adalah Seyyid Nur Muhammad yang mengajarinya aliran dan tariqat (țarīqah) Naqsybandī, ${ }^{20}$ Syaikh Abdurrahman Tagi, gurunya dalam memelajari "jalan cinta" (muhabbet); Syaikh Fehim, guru yang mengajarinya "pemahaman tentang kenyataan" ('ilm-i hakikat), dan Syaikh Muhammad Kufrevi, darinya dia menerima pelajaran terakhirnya. Disebutkan juga bahwa ada tiga ulama terkemuka yang telah mengajar Said Nursi dan sangat dicintai: yaitu Syaikh Emin Efendi dari Bitlis, Molla Fethullah dari Siirt, dan Syaikh Fethullah Verkanisi. Daftar singkat ini menggambarkan sebuah titik penting bahwa kebanyakan ulama terkemuka Anatolia Timur pada akhir abad ke-19 tampaknya muncul dari aliran Naqsybandīyah Khālidīyah. ${ }^{21}$ Mungkin karena ketradisionalannya serta jauhnya jarak dari ibukota, membuat sangat sedikit terdapat orang yang terpelajar secara formal dari kawasan ini. ${ }^{22}$ Dan hal ini yang menjadi motivasi Said Nursi dalam memandang sangat pentingnya reformasi pendidikan secara menyeluruh.

Akan tetapi, dengan perjalanan hidup yang sangat sederhana dan dekat dengan tradisi, bukan berarti ia tidak mengetahui dan tidak memahami ilmu-ilmu modern maupun kontemporer seperti ilmu falsafat, ilmu matematika, fisika, geografi, maupun politik. Ia, dengan kelebihan yang dimiliknya dan kejeniusan yang ada padanya, mampu memelajari dan memahami ilmu-ilmu tersebut tanpa diajari oleh seorang guru dengan cara menempuh pendidikan formal di lembaga- 
lembaga pendidikan tertentu. Ia memelajari dan dapat menguasainya dengan kelebihan yang dia punyai dan juga kebersihan hatinya sehingga dapat diberikan kemudahan pemahamannya oleh Allah.

Proses pembelajarannya terhadap ilmu-ilmu kontemporer tersebut didapatkan ketika ia berada di Van pada tahun 1892 M. Selama di sana, ia bertemu dengan banyak tokoh dan orang-orang yang menguasai berbagai disiplin ilmu modern yang kemudian menjadi teman diskusinya. Dengan memergunakan perpustakaan dan koran-koran serta jurnal-jurnal yang disediakan di kantor Tahir Pasya, Said Nursi mulai memelajari subjek-subjek ilmu pengetahuan seperti sejarah, geografi, matematika, geologi, fisika, kimia, astronomi, fisika dan falsafat, permasalahan terkini, perkembangan-perkembangan dalam kehidupan 'Utsmānī serta dunia Islam.

Said Nursi melanjutkan memelajari buku-buku yang dia anggap berarti tersebut, dan sekitar sembilan puluh judul buku pada masamasa dia berada di Van telah dibacanya. Dan pada saat inilah, karena hasil prestasinya, serta kecerdasan yang dia miliki, Said Nursi dikenal secara meluas dengan sebutan Badī' al-Zamān"3 atau "Keajaiban Zaman", nama yang diberikan kepadanya beberapa tahun sebelumnya oleh Molla Fethullah dari Siirt. ${ }^{24}$

\section{Karya-karya Ilmiah Bediuzzaman Said Nursi}

Bediuzzaman Said Nursi adalah seorang intelektual yang produktif dalam menghasilkan karya. Ini terbukti dari karya-karya yang ia hasilkan dan telah disebarluaskan. Adapun masterpiece karya Nursi adalah Risālah al-Nür.

Risālah al-Nūr atau dikenal juga dengan Kullīyah al-Rasāil alNūr adalah kumpulan kitab tafsir yang ditulis oleh Said Nursi dalam berbagai tema dan pembahasan. Adapun yang dimaksud Risālah al-Nūr adalah kumpulan tulisan Said Nursi secara keseluruhan, yang kemudian oleh Iḥsān Qāsim al-Ṣāliḥ̄i diterjemahkan ke dalam bahasa Arab dan dicetak kedalam 10 jilid besar. Risālah alNūr adalah karya monumental Said Nursi yang ditulisnya dengan tulisan tangan bersama murid-muridnya yang tebalnya mencapai kurang lebih 6000 halaman, yang di dalamnya terdapat karyakarya Said Nursi yang ditulis pada masa Said Qadìm dan Said 
$\operatorname{Jadī}^{25}$.

Karya Bediuzzaman Said Nursi Risālah al-Nūr ini terdiri dari empat bagian besar, yaitu Sözler atau al-Kalimāt yang terdiri dari 33 risalah, kemudian Mektubat atau al-Maktübāt yang terdiri 33 risalah, kemudian Lem'alar atau al-Lama'àt yang terdiri dari 33 risalah juga, dan Şu'alar atau al-Syu'ààt yang terdiri dari 15 risalah.

Karya al-Maktūbāt hakikatnya merupakan risalah ke 33 dari karya al-Kalimāt, yang kemudian disusun tersendiri menjadi 33 risalah lagi. Kemudian karya al-Lama'àt hakikatnya merupakan risalah ke 31 dari kitab al-Maktūbāt, yang disusun tersendiri menjadi 33 risalah. Selanjutnya al-Lama'āt hakikatnya adalah risalah ke 31 dari kitab al-Lama'ăt, yang disusun tersendiri menjadi 15 risalah.

Adapun kitab Isyārāt al-I jōzz merupakan risalah ke 30 dari kitab al-Maktūbāt yang diberi judul tersendiri, begitu juga kitab al-Matsnawì al-'Arabì al-Nūrì merupakan risalah ke 33 dari kitab al-Lama'àt yang diberi judul tersendiri, sedangkan kitab alMala> hiq adalah risalah ke 27 dari kitab al-Maktūbāt, yang dibagi menjadi tiga bagian, yaitu Mulhaq Bārlā, Mulhaq Kastamonī, dan Mulhaq Amīrdāg. Sedangkan risalah ke 32 dari kitab al-Maktūbāt dan al-Lama'àt diberi nama dengan al-Lawāmi' yang berisikan tentang kumpulan kata-kata puitis tentang keimanan oleh para murid Said Nursi (Țullāb al-Nür). Kemudian risalah ke 15 dari kitab al-Lama'ät berupa daftar isi keseluruhan dari Risālah al-Nūr, sedangkan risalah ke 10 dari kitab al-Syu'àāt berisikan daftar isi kitab al-Syu'a'āt saja. ${ }^{26}$

Itulah karya-karya Said Nursi yang terangkum dengan sebuah judul besar Risālah al-Nür atau Kullīyāt Rasäìl al-Nür. Secara global isi pokok dalam karya Risālah al-Nür tersebut mengupas tentang aqidah dan keimanan yang diindikasikan dengan ma'rifat Allah, ma'rifat Rasulullah, melalui manhaj al-Sunnah; penguatan aspek ibadah, akblak dan moralitas atau adab-adab Islami dan lain-lain.

Keberadaan Risālah al-Nür merupakan sumber dari pembahasan karya-karya Said Nursi yang kemudian dikumpulkan secara tematis menjadi buku-buku lain. ${ }^{27}$ Dan karya-karya Nursi dalam Risälah an-Nür telah diterjemahkan ke dalam sekitar 40 bahasa lebih, ${ }^{28}$ dan 
meluas dipelajari oleh jutaan orang di seluruh penjuru dunia.

\section{Proses Modernisasi di Turki}

Perkembangan modernisasi di Turki sekarang ini merupakan kelanjutan atas perjalanan perjuangan panjang rakyat Turki untuk dapat menemukan formulasi ideal bagi kesejahteraan masyarakat yang telah dimulai sejak lama. Para tokoh dan gerakan yang mewarnainya juga berbeda dengan membawa visi yang beraneka ragam, dengan kepentingan dan tujuan yang melatar belakanginya. Proses modernisasi Turki adalah proses perdebatan panjang yang terjadi di antara para pembaharu Turki tentang bagaimana menyikapi ide-ide Barat, ajaran Islam, dan budaya lokal Turki. ${ }^{29}$

Gerakan modernisasi di Turki secara garis besar terbagi menjadi tiga kelompok, ${ }^{30}$ yaitu: pertama gerakan yang berorientasi dan masih berpegang ketat pada prinsip-prinsip Islam, yang disebut Islamisme. Kedua, gerakan yang banyak mengadopsi pemikiran, sikap hidup, atau terilhami oleh peradaban Barat, kelompok ini dinamakan Westernisme. Ketiga, gerakan yang menitikberatkan aspek keaslian Turki atau secara kenegaraan mereka selalu mementingkan sikap, pola pikir dan tindakan yang bersandar pada nilai-nilai lokal Turki. Rasa cinta Tanah Air, dan patriotisme yang tinggi membawa mereka lebih mengutamakan nasionalisme di atas segala-galanya. Kelompok ini dinamakan kelompok Nasionalisme. ${ }^{31}$

Pertama, kelompok Islamisme terdiri dari para pembaharu yang memunyai komitmen kuat atas nilai-nilai Islam, dan mereka berpegang pada prinsip-prinsip Islam dalam menapaki alur pembaruan. Mereka berusaha untuk menggabungkan antara pemikiran-pemikiran modern dengan nilai-nilai Islam. ${ }^{32}$

Organisasi terpenting dari kelompok ini dikenal dengan sebutan Sirat-i Mustakim (Jalan Lurus), yang mencakup orang-orang seperti Said Halim Pasha, Mahmud Akif (1870-1936), dan Eşraf Edif. Hingga pada tahun 1912 kelompok ini terkenal dengan Sebilürreşat (Jalan Kebajikan). ${ }^{33}$ Mereka berpendapat bahwa agama Islam tidak pernah menghambat kemajuan. Menurut golongan Islam, kelemahan umat Islam selama ini tidak terletak pada syari'at, tapi terletak pada syari'at yang tidak dijalankan dengan semestinya oleh umat Islam terutama sekali oleh khalifah 'Utsmānī. Agar umat Islam tidak mundur, maka 
syari'at ini perlu untuk dijalankan. Pada tahun 1909 kelompok Islam pernah mengajukan konsep syari'at ke dewan parlemen. ${ }^{34}$

Menurut golongan ini, konstitusi tahun 1876 dianggap tidak tepat, ${ }^{35}$ karena dianggap tidak sesuai dengan moral Islam dan kondisi sosial politik Turki pada waktu itu, sehingga simbol Islam sebagai agama dalam bernegara tidak sesuai, juga khalifah yang tidak memerintah berdasarkan nilai-nilai Islam akan cenderung melenceng, karena kontrol moral yang berdasarkan hukum Tuhan tidak dimilikinya.

Dalam masalah persamaan hak antara laki-laki dengan perempuan, pendapat mereka masih bias gender, bahkan menurut Musa Kazim -salah seorang tokoh golongan ini- perempuan tidak bisa diberi hak dan status yang sama dengan laki-laki, karena perempuan memunyai tingkat emosional yang berbeda dari laki-laki. Senada dengan pendapat ini adalah Said Halim yang menurutnya bahwa peradaban sering kali jatuh justru karena kebebasan yang diberikan pada perempuan.

Mereka tidak pernah menolak kemajuan ilmu pengetahuan dan teknologi yang mungkin datangnya dari Barat, bahkan mereka setuju dengan dimasukkannya ke dalam kurikulum sekolah madrasah, akan tetapi mereka menolak konsep sekularisasi yang diterapkan melalui modernisasi pendidikan. Golongan Islam ini juga tidak menentang konsep-konsep ekonomi modern, hanya saja mereka tidak menerima konsep kapitalisme dan ekonomi individual ala Barat, di samping kelompok ini juga menolak sistem ekonomi sosialis. ${ }^{36}$

Erik J. Zürcher memasukkan gerakan Nurculuk (para pembaca Risālah al-Nūr atau para murid Bediuzzaman Said Nursi), termasuk pada gerakan modernis Islam penting yang muncul pada periode konstitusional kedua atau sekitar tahun 1930-an. ${ }^{37}$ Nursi pernah menjalin hubungan dengan para tokoh Turki Muda, hingga kemudian akhirnya bergabung dengan gerakan kontra revolusi yaitu gerakan Persatuan Muhammad (Al-Ittị̧ād al-Muhammadīi ${ }^{38}$ pada tahun 1909, dan Nursi juga sempat menjadi propagandis Teşkilāt-i Mahsusa ${ }^{39}$ pada Perang Dunia I. Nursi pada sisi lain mendukung gerakan perlawanan nasional, akan tetapi dia juga mengingatkan tendensitendensi sekularisnya di tahun 1923. Sejak tahun-tahun pertama di 
abad itu, Nursi meraih reputasi sebagai seorang ahli agama terutama di daerah Timur, yang memunyai pengaruh besar dengan karyanya Risālah al-Nür. ${ }^{40}$ Akan tetapi gerakan modernis Islam yang dibawa Said Nursi memunyai konsep dan warna yang tidak bisa dianggap sama dengan para pembaharu Islam di atas. Dan secara lebih detail, akan dipaparkan penulis ke dalam pembahasan tersendiri.

Kelompok kedua, gerakan Westernisme adalah gerakan yang terdiri dari orang-orang Barat yang memunyai idealisme Barat, atau para tokoh intelektual Turki yang terbaratkan pemikiran dan perilakunya. Golongan ini disebut dengan gerakan Westernisme karena banyak mengakomodasi pemikiran Barat dalam semua aspeknya.

Gerakan Westernisme meloloskan ide-ide sekularisme ${ }^{41}$ dalam basis kekuatannya. Mereka berupaya untuk mengadopsi pemikiran Barat secara intensif, sehingga aspek sosial kemasyarakatan selalu diteropong dengan pandangan-pandangan sekular. Golongan ini terdiri dari beberapa tokoh yang dalam gerakan pembaruan di Turki sebelumnya juga sudah banyak mengedepankan pemikiran Barat secara intensif. Namun tokoh yang dianggap memunyai kapabilitas dan representatif bagi pemikiran-pemikiran tokoh sebelumnya adalah Tawfik Fikret (1867-1951), seorang pemikir sekaligus sastrawan yang banyak mengritik dan menentang kaum tradisional. Tokoh Westernizer ekstrem lainnya adalah Abdullah Cevdat (1869-1932), Seorang intelektual bergelar doktor yang dianggap salah satu pendiri Komite Persatuan dan Kemajuan. ${ }^{42}$ Mereka berkeinginan untuk meninggalkan Peradaban 'Utsmānī yang tradisional dan mengadopsi cara-cara Eropa sepenuhnya sebagai penggantinya. ${ }^{43}$

Mereka banyak mengritik ulama tradisional yang dianggapnya telah membawa umat Islam ke dalam kemunduran. Kiritk-kritik mereka adalah mengenai taqlid buta pada para ulama, sikap menerima taqdir dan berserah total pada nasib yang cenderung fatalis, sehingga mengakibatkan masyarakat enggan untuk melakukan perubahan, belum lagi ditambah bahwa umat Islam masih terjangkit penyakit bodoh dan malas. Kelemahan umat Islam saat itu bukan terletak pada ajaran Islam tapi terletak pada sistem sosial yang berdasar pada tradisi Islam dan sistem kekhalifahan.

Sistem pemerintahan perlu disekularisasikan untuk memerjelas 
kepentingan bernegara yang berdasar negara, dan kepentingan agama hanya berdasarkan agama. Rasionalisasi pemikiran harus dilakukan, Barat dapat maju karena menerapkan sikap rasionalitas dalam kehidupannya dan rasionalitas itu menjadi pilar-pilar ilmu pengetahuan dan teknologi, serta menjadi dasar mereka dalam beragama, yaitu agama yang rasional. Rasionalisasi dalam beragama mereka lakukan dengan menafsirkan al-Qur'ān maupun Sunnah sesuai dengan tuntutan zaman. Islam harus kontekstual dan diusahakan cocok dengan pemikiran modern. ${ }^{44}$

Dalam masalah persamaan hak antara laki-laki dan perempuan, mereka sangat antusias untuk memberikan hak dan kedudukan yang setara antara laki-laki dengan perempuan. Bahkan dalam hal ini Abdullah Cevdat mengatakan dalam tulisannya: "Bukalah alQur'ān dan bukalah kerudung wanita”. Poligami juga dianggap hal yang merendahkan kedudukan perempuan, sehingga mereka menuntut untuk dihapuskan. Peradaban Barat dapat maju karena mereka memberikan kedudukan yang sama antara laki-laki dengan perempuan. ${ }^{45}$

Golongan selanjutnya adalah gerakan Nasionalisme, yaitu gerakan yang berusaha untuk mencari berbagai alternatif dalam memecahkan berbagai permasalahan kehidupan rakyat Turki dengan mencoba menyintesakan antara ide-ide Westernisme dan pemikiranpemikiran Islamisme. Usaha ini mereka lakukan untuk kepentingan yang mendesak, mengingat terpecahnya berbagai golongan di Turki karena banyaknya kepentingan di antara rakyatnya. Beberapa tokoh penting gerakan ini antara lain: Yusuf Akçura (1876-1933), Ziya Gökalp (1875-1924) dan Mustafa Kemal Attaturk (1881-1938).

Yusuf Akçura merupakan tokoh pembaharu yang mengedepankan pemikiran untuk penghimpunan masyarakat Turki. Ia berusaha menyatukan visi masyarakat Turki baik yang ada di wilayah itu maupun mereka yang berada di wilayah Rusia (Kazan), Krimea, dan Azerbaijan sebagai satu bangsa. Pada saat itu ada tiga kekuatan yang berbeda di dalam kerajaan 'Utsmānī. Mereka dari golongan Islam, Rakyat Turki dan Rakyat bukan Islam. ${ }^{46}$ Dia mengatakan bahwa penciptaan bangsa Turki dari berbagai unsur yang ada di bawah kerajaan adalah suatu ilusi, karena negara-negara kolonial akan selalu 
menghadang upaya-upaya untuk menciptakan suatu persatuan politis yang dilakukan oleh umat Islam sedunia, tetapi berbeda jika yang dikembangkan adalah Pan-Turkisme -persatuan bahasa dan bangsa Turki- maka akan didukung oleh semua bangsa Turki. ${ }^{47}$

Ide Nasonalisme selanjutnya dikembangkan oleh Ziya Gökalp, yang dianggap paling konsisten dalam menyintesakan berbagai unsur dalam warisan 'Utsmānī (Islam, etnisitas Turki dan negara 'Utsmānī) dengan modernisasi madzhab Eropa. Menurut Gökalp, bangsa Turki memiliki kulturnya sendiri yang kuat, menyatu dengan peradaban Abad Pertengahan yang sebagian adalah Arab-Islam dan sebagian lagi Bizantium. Solusi terbaik menurutnya adalah dengan mengganti peradaban ini dengan peradaban Eropa yang modern, dengan tetap berpegang pada kultur Turki ${ }^{48}$ (yang menurutnya adalah sebagai peradaban murni dari bagian kultur Islam). Kegagalan reformasi Tanzimat adalah karena penggabungan dengan peradaban Eropa yang menghilangkan kultur mereka sendiri. ${ }^{49}$

Dalam kehidupan bernegara, Turki harus berdasar hukum perundang-undangan modern. Turki hendaknya mereproduksi kembali nilai-nilai hukum yang saat ini berkembang di Barat dan disesuaikan dengan kondisi rakyat Turki. Turki tidak perlu memakai syari'at Islam sebagai dasar negara. Negara hanya dapat berjalan berdasarkan perundangan negara, bukan perundangan agama. Agama perlu dipisahkan secara tegas dari kepentingan negara, begitu juga sebaliknya. Secara administratif, Turki perlu menata sistem pemerintahannya. ${ }^{50}$ Jadi sekularisai dalam sistem pemerintahan masih dipertahankan.

Pemindahan kekuasaan Mahkamah Syari'ah dari jurisdiksi "Syaykh al-Islām" menuju kepada Kementerian Kehakiman, begitu juga pemindahan madrasah dari kekuasaan Syaykh kepada Kementerian Pendidikan dan seterusnya adalah keharusan. Meskipun Mahkamah Syari'ah bisa diberlakukan, namun fungsinya dialihkan pada aktivitas mu'amalah saja. Jadi masalah-masalah agama berada pada wewenang ulama, sedangkan masalah-masalah kenegaraan berada di bawah kekuasaan pemerintah. Dengan demikian negara mutlak berdasarkan nilai-nilai sekular.

Sejumlah permasalahan yang berkaitan dengan isu-isu pembaruan 
modern seperti kedudukan, peranan dan hak wanita -yang sebelumnya diajukan oleh golongan Westernisme- mulai mendapat tanggapan dan disetujui oleh kaum Nasionalis. Wanita harus diikutsertakan dalam pergaulan sosial dan kehidupan ekonomi. Di Barat wanita memunyai hak dan kebebasan yang tinggi, sehingga kaum wanita dapat mengiringi kemajuan yang dicapai oleh kaum laki-laki. Sehubungan dengan hal ini, kaum Nasionalis juga menghapus ketentuan hukum seperti masalah perceraian, perkawinan, dan poligami yang ada dalam hukum syari'at.

Dalam bidang pendidikan, mereka berusaha untuk menciptakan sistem pendidikan yang khusus sesuai dengan kebudayaan Nasional Turki sendiri, tidak berdasarkan Islam, akan tetapi berazaskan nilainilai sekuler modern. ${ }^{51}$

Aplikasi ide pembaruan yang diusung oleh ketiga golongan di atas, meskipun masing-masing nampak terdapat perbedaan, namun fokus dan perhatian yang ingin dicapai adalah kemajuan rakyat Turki yang modern. Secara umum, permasalahan-permasahan yang ditanggapi dan yang mendapat perhatian mereka adalah mencakup tiga hal, yaitu pertama, masalah hubungan agama dan Negara: apakah Islam masih perlu dipertahankan untuk diterapkan dalam negara, atau ditolak sama sekali, atau hanya diambil nilai-nilainya. Kedua, masalah ilmu pengetahuan dan teknologi yang sedang berkembang di Barat dengan trend positivis, ataukah tetap memertahankan ilmu agama dan kebenaran agama, dan direalisasikan dalam sistem pendidikan, serta ketiga, masalah kontemporer tentang isu aktual tentang persamaan hak perempuan. Meskipun tindakan-tindakan yang mereka tempuh tidak serta merta mengubah Turki menjadi modern, akan tetapi apa yang mereka lakukan adalah proses menuju hasil terwujudnya Turki modern sekarang ini.

\section{Nasionalisme di Turki}

Nasionalisme Turki merupakan faham yang relatif baru, dan pada awalnya muncul sebagai sebuah gerakan kultural pada dua dekade terakhir masa pemerintahan Sultan Abdul Hamid. Nasionalisme bermula dari karya para Orientalis Eropa, seperti dua orang Perancis bernama de Guignes dan Cahun, serta seorang Hongaria bernama 
Vambery yang memelajari warga Turki Asia Tengah di abad ke-19 dan mengaji pula pengaruh Kerajaan Rusia terhadap warga Turki, terutama warga Tatar dan Azeris. Tokoh Turki dari Rusia yang aktif di Kerajaan 'Utsmānī adalah orang Azeris bernama Huseinzade Ali (Turan) dan Ağaoğlu Ahmet, serta orang Tatar bernama Yusuf Akçura dan juga Ziya Gökalp. ${ }^{52}$

Berbeda dari tokoh-tokoh Nasionalisme di atas, Mustafa Kemal Attaturk merupakan tokoh nasionalis yang berusaha menggabungkan semua kepentingan, baik Islam, Barat, maupun nasionalisme Turki. Walaupun ide keislaman berada pada pertimbangan paling akhir dalam pertimbangan kepentingan jika dibandingkan dengan ide-ide nasionalisme dan ide Barat, bagaimanapun Islam tetap menjadi bagian yang tak terpisahkan dari pemikiran Mustafa Kemal Attaturk. ${ }^{53}$

Westernisme, sekularisme, dan nasionalisme merupakan dasar pemikiran pembaruan Mustafa Kemal. Pembaruan pertama ditujukan pada bentuk negara. Pemerintah harus dipisahkan dari agama atau sekular. Makna konsep Sekularisme Kemalis adalah pelaksaan strategi modernisasi yang berlandaskan pada visi dunia positivis, di mana agama dipandang sebagai penghambat kemajuan dalam proses modernisasi masyarakat dan negara. Sekularisme mereka, menurut pendapat Zürcher, bukan berarti pemisahan antara agama dan negara, tetapi lebih cenderung pada pengendalian dan integrasi agama ke dalam birokrasi negara. ${ }^{54}$

Nasionalisme yang diusung Mustafa Kemal adalah nasionalisme yang secular. Dia menempatkan agama di bawah kontrol pemerintah. sedangkan sekularisasi yang dibawa adalah sinonim dengan Westernisasi. Konsep nasionalisme dipahami bukan dalam konteks lokal Turki, akan tetapi dalam konteks Barat. Bangsa Turki akan eksis bukan sebagai kelompok rakyat yang memiliki kesamaan masa silam, akan tetapi sebagai kelompok rakyat yang memiliki kesamaan masa depan di antara bangsa-bangsa Barat yang berperadaban. ${ }^{55}$

Meskipun demikian, Mustafa Kemal sebagai tokoh Nasionalis dan juga pengagum peradaban Barat, akan tetapi dia tidak menentang agama Islam. Baginya Islam adalah agama yang rasional, tetapi rasionalitasnya telah dirusak oleh pemeluknya. Oleh sebab itu, ia melihat perlunya pembaruan dalam bidang agama supaya 
disesuaikan dengan bumi Turki. Al-Qur'ān perlu diterjemahkan ke dalam bahasa Turki, agar dapat difahami oleh rakyat Turki. Demikian juga khutbah Jumat harus disampaikan dalam bahasa Turki. Begitu juga adzan dalam bahasa Turki mulai diberlakukan pemakaiannya di tahun $1931 . .^{56}$

Sekularisasi yang dijalankan Mustafa Kemal tidak sampai menghilangkan agama. Sekularisasinya berpusat pada menghilangkan kekuasaan agama dari bidang politik dan pemerintahan. Oleh karena itu, pembentukan partai yang berdasarkan agama dilarang. Negara harus dipisahkan dari agama. Institusi-institusi negara, sosial, ekonomi, hukum, politik, dan pendidikan harus dibebaskan dari kekuasaan agama dan syari'at, akan tetapi negara tetap menjamin kebebasan beragama bagi rakyatnya. ${ }^{57}$

Kebijakan-kebijakan maupun undang-undang untuk mendukung proyek pembaharuan dan nasionalisme Turki terus digalakkan. Akan tetapi tidak lama setelah Mustafa Kemal meninggal pada 10 November 1938, gerakan-gerakan purifikasi serta seruan untuk kembali kepada agama mulai santer dan bermunculan kembali. Hal ini dikarenakan rasa keagamaan yang telah mengakar kuat pada masyarakat. Islam telah menyatu pada sistem sosial masyarakat Turki, sehingga upayaupaya modernisasi dengan cara nasionalisme yang sekular masih belum berhasil.

\section{Turki di Era Modern ${ }^{58}$}

Cita-cita yang digagas oleh pemerintah Republik Turki di bawah gagasan-gagasan pembaruan, berupa Nasionalisme yang dikembangkan Mustafa Kamal tidak serta merta membawa Turki ke arah yang sangat modern seperti yang dicita-citakan. Semasa Kemal masih hidup, pembaruan berjalan lancar meskipun banyak memeroleh tentangan dan tantangan dari para golongan Islam tradisional. Akan tetapi setelah Kemal wafat, Nasionalisme dan Sekularisasi yang digagasnya semakin melemah. Pamornya makin berkurang karena kuatnya tradisi Islam yang telah berakar pada masyarakat Turki, sehingga sulit dipengaruhi dengan ide-ide Barat. Masyarakat Turki memunyai ikatan batin yang kuat dengan Islam sebagai agama yang telah mereka anut semenjak berabad-abad lalu yang nilai-nilainya 
telah tertanam dalam tradisi kehidupan mereka. ${ }^{59}$

Semenjak tahun 1940-an, aktivitas-aktivitas keislaman mulai dihidupkan kembali, imam-imam tentara sudah diaktifkan lagi di dalam Angkatan Bersenjata Turki. Pada tahun 1949 pendidikan agama mulai dihidupkan kembali dan bahkan dijadikan mata pelajaran wajib di sekolah, setelah sebelumnya sempat dihapuskan. Mulai tahun 1950, pelarangan ibadah haji sebelumnya dengan alasan pemborosan ekonomi, mulai dicabut. Lembaga penerbitan Islam kembali menyiarkan ide-ide keislamannya. Para buruh dan petani yang dulu takut untuk mengikuti ajaran tariqah, nampak kini mulai berkembang. Organisasi-organisasi politik Islam yang dulu dibubarkan dan dimusuhi penguasa pembaharu, juga mulai memainkan peranannya. ${ }^{60}$

Melihat kondisi ide-ide pembaruan yang banyak terilhami oleh semangat nasionalisme dan sekularisasi yang semakin terdesak dan semakin tidak popular, maka ide-ide yang berorientasi pada pemurnian nilai-nilai Islam mulai mendapat perhatian baru. Sejumlah tokoh yang meskipun tidak antipati pada ide pembaruan, namun sangat berkompeten untuk menegakkan citra Islam, mencoba membangun kembali kekuatan Islam yang berbeda dari sebelumnya. Dalam hal inilah Bediuzzaman Said Nursi dan juga para pengikutnya banyak berperan untuk membangkitkan kembali semangat dan nilainilai Islam di Turki. ${ }^{61}$

Hingga pada tahun 1950-an, terkenal sebuah kelompok yang bernama Nurcus, yang sebelumnya pada tahun 1930-an gerakan ini dikenal dengan sebutan Nurculuk (para pembaca Risālah alNür atau para murid Bediuzzaman Said Nursi). Meskipun Nurcus menglaim diri mereka tidak terlibat dalam dunia politik, akan tetapi publikasi-publikasi yang mereka lakukan menunjukkan dengan jelas bahwa mereka menentang ide "Republik Sekular" yang menerapkan nasionalisme kebarat-baratan dan ingin merestorasi menjadi nasionalisme yang bernafaskan Islam. ${ }^{62}$

Dalam kehidupan bernegara, konstitusi Turki tahun 1961 -yang berlaku sampai sekarang ini- mengatur agama baik dalam teksnya sendiri maupun dalam rujukannya kepada serangkaian hukum organis. Walaupun kekuatan pesan yang terkandung dari konstitusi 
ini merupakan amandemen yang mengandung kekuatan atas produk hukum sebelumnya, namun pada intinya telah memberi peluang baru bagi Islam sebagai ajaran moral yang mengikat dalam kehidupan bermasyarakat dan bernegara serta mengindikasikan adanya hakikat pembebasan atas pemberlakuan Islam sebagai pilihan masyarakat.

Tak terkecuali dalam bidang sosial-keagamaan, bahwa segala aspek modern mulai diperhatikan. Ini dimulai dengan perkembangan isu kesetaraan gender dan gerakan feminisme di Turki yang mulai bermunculan di tahun 1980-an. Pada tahun 1982 di Istanbul dilaksanakan sebuah simposium yang membahas tentang isu feminisme. Pada tahun 1983 sebuah grup feminis menerbitkan buletin Somut yang membahas tentang isu-isu perempuan di dalamnya. Dan pada tahun 1984 sekelompok feminis Istanbul mendirikan organisasi publik pertama kalinya yang diberi nama "Women Circle". Pada tahun 1986 di Istanbul dan Ankara kelompok feminis bersama-sama membuat satu kampanye, yang berisi sebuah petisi pada pemerintah untuk menghilangkan segala macam diskriminasi dan penindasan pada perempuan. ${ }^{63}$ Dalam masalah kebebasan berjilbab, akhirnya pada tanggal 10 Februari 2008, parlemen menyetujui pencabutan larangan berjilbab di kampus. Sebanyak 401 anggota parlemen menyatakan setuju, sedangkan hanya 110 yang menolaknya. ${ }^{64}$

Turki dewasa ini hanya meninggalkan sejarah tentang upaya modernisasi yang dijiwai oleh nasionalisme sekular yang kurang berhasil. Selain faktor sosial, politik, dan ekonomi, faktor keadilan sosial merupakan faktor yang sangat penting bagi masyarakat Turki, dan masyarakat Turki menyandarkan harapannya kepada jalur-jalur nilai Islam untuk mewujudkan cita-cita keadilan sosial ini. ${ }^{65}$ Citra Turki pada tiga dekade terakhir semakin menampakkan penekanan agama sebagai solusi untuk memeroleh legitimasi kekuatan dalam masyarakat luas. Dengan asumsi tersebut, maka Turki akan "kembali menjadi Muslim” baik secara esensial maupun eksistensial dalam setiap dimensi kehidupan di masa mendatang.

\section{Keterpengaruhan Penafsiran oleh Modernisasi Turki}

Seseorang adalah produk dari zamannya. Ungkapan ini secara sederhana menerangkan bahwa seseorang pasti tidak akan bisa terlepas 
dari kehidupan sosialnya, yang pada akhirnya akan membentuk pribadinya dan memengaruhi pemikirannya. Tak terkecuali hal tersebut akan dialami juga oleh seorang mufassir yang pada akhirnya akan memengaruhi pemikiran dan penafsirannya.

Nursi adalah seorang ulama dengan visi yang kuat untuk menyatukan dunia Islam yang sedang retak-retak. Perjuangan dan karya-karya Nursi memberikan wawasan luas dan gambaran yang mendalam tetang masa sejarah pasca Tanzimat di Turki. Di samping masalah keimanan yang menjadi fokus utama Nursi waktu itu, yang menyebabkan bobroknya moral masyarakat, pokok tema dalam penafsiran Nursi juga banyak merespon isu relevansi tentang negara Islam, apakah masih patut diperjuangkan sebagai dasar negara atau tidak, dan juga pembahasan tentang hubungan antara Islam dan modernisasi yang berbentuk nasionalisme secular. ${ }^{66} \mathrm{Di}$ samping juga yang tidak kalah pentingnya ialah masalah keadilan dan persamaan hak antara laki-laki dan perempuan, yang juga menjadi pembahasan mendapat perhatian khusus oleh Nursi.

Dalam pembahasan ini penulis memfokuskan pembahasan pada tiga hal di atas yang menjadi isu penting ketika dikaitkan antara pengaruh modernisasi yang terjadi di Turki terhadap penafsiran Bediuzzaman Said Nursi, yaitu hubungan agama dan negara: mengenai seputar pertanyaan yang muncul apakah Islam masih perlu dipertahankan untuk diterapkan dalam bentuk negara, atau ditolak sama sekali, ataukah hanya diambil nilai-nilainya dan dikompromikan dengan budaya lokal. Kemudian masalah perkembangan ilmu pengetahuan dan teknologi Barat: apakah akan menerima begitu saja segala macam ilmu pengetahuan Barat yang dipenuhi dengan falsafat materialis dan falsafat empiris yang ateis, ataukah tetap memertahankan ilmu agama dan kebenaran agama sebagai hakikat tertinggi, kemudian menggabungkan keduanya untuk saling melengkapi. Dan Juga masalah kontemporer tentang isu aktual tentang persamaan hak antara perempuan dan laki-laki: apakah perempuan memunyai hak bebas penuh maupun kewajiban yang sama persis dengan laki-laki, ataukah hubungan antara perempuan dan laki-laki itu merupakan hubungan yang saling menyempurnakan kekurangan masing-masing untuk menuju kesejahteraan hidup. Tiga 
hal inilah yang kemudian akan menjadi fokus penelitian penulis.

\section{Islamisasi Ilmu Pengetahuan}

Perkembangan ilmu pengetahuan adalah aspek paling penting yang dibutuhkan oleh suatu masyarakat, karena setiap sendi kehidupan bermasyarakat pasti berhubungan dengan ilmu pengetahuan. Maju dan berkembangnya kehidupan suatu masysrakat tidak lepas dari perkembangan ilmu pengetahuan yang dimilikinya.

Setiap pemikir maupun ulama, pasti memberikan perhatian khusus terhadap ilmu pengetahuan, tak terkecuali Nursi yang menekankan pentingnya pembelajaran dan pengembangan ilmu pengetahuan bagi suatu masyarakat. Kekuasaan dan aturan-aturan akan dipengaruhi oleh ilmu pengetahuan tersebut, karena setiap masyarakat akan diatur oleh ilmu pengetahuan yang berkembang pada masanya.

Ilmu pengetahuan adalah apa yang diberikan oleh Allah pada mahluk-Nya melalui al-Qur'ān, karena al-Qur'ān adalah sumber segala pengetahuan secara universal. Dalam al-Baqarah/2: 31 Allah berfirman: "Dan dia mengajarkan kepada Ādam nama-nama (bendabenda) seluruhnya, kemudian mengemukakannya kepada para malaikat lalu berfirman: Sebutkanlah kepada-Ku nama benda-benda itu jika kamu memang benar orang-orang yang benar."

Allah mengajarkan segala sesuatu kepada Nabi Ādam sebagai manusia pertama di muka bumi untuk mengenal alamnya. Nursi menyatakan:

Al-Qur'ān berisi peristiwa-peristiwa yang sekilas tampak tidak penting. Masing-masing peristiwa menyembunyikan sebuah prinsip universal dan menyajikan gagasan awal dari sebuah ketentuan umum. Sebagai misal ayat: (Dia) mengajarkan kepada Ádam namanama kesemuanya (al-Baqarah/2:1) menyatakan bahwa Ādam diajari "nama-nama" merupakan mukjizat yang menunjukkan superioritas Ādam dibanding para malaikat berkat kesesuaian martabatnya sebagai khalifah Allah di bumi. Itu merupakan suatu ketentuan Allah di muka bumi, walaupun tampaknya sebagai sebuah peristiwa remeh dan sederhana, dan kejadian ini telah membentuk titik awal bagi sebuah prinsip universal: karena sifat Ādam yang käffah, komprehensif, 
maka umat manusia diberikan potensi untuk memeroleh sejumlah besar informasi, ilmu-ilmu yang berkenaan dengan segala aspek jagad raya serta pengetahuan yang luas tentang sifat dan tindakan Sang Pencipta. Semua ini menjadikan umat manusia lebih unggul dibanding para malaikat, langit, bumi, dan gunung-gunung, karena hanya manusialah yang sanggup memikul "Amanah Agung". Itulah yang mendudukkan umat manusia sebagai pengatur bumi atas nama Allah." ${ }^{67}$

Ilmu pengetahuan akan berkembang secara bertahap menuju arah penyempurnaan. Apa yang dulu masih berupa angan-angan dan khayalan, bisa menjadi kenyataan pada masa datang. Temuan dan perkembangan ilmu pengetahuan yang pesat dan beragam macamnya seperti sekarang ini, berawal dari induk falsafat yang telah dikembangkan oleh para failasuf termasuk juga oleh para failasuf Islam seperti Ibn Sīnā. Perkembangan ilmu pengetahuan merupakan perkembangan anti klimaks menuju kesempurnaan ${ }^{68}$.

Untuk menglasifikasi ilmu pengetahuan, Nursi mengatakan bahwa ilmu dibagi menjadi dua, yaitu ilmu pengetahuan positif (al'Ulūm al-Mãdìyah) ${ }^{69}$ atau disebut dengan ilmu umum, dan ilmu pengetahuan metafisika (al-'Ulüm al-Ilāhìyaht) atau disebut juga dengan ilmu agama. Ilmu pengetahuan positif adalah ilmu yang membutuhkan keberadaan ilmu-ilmu lain dan juga memerlukan pembuktian kebenarannya, berbeda dai ilmu pengetahuan metafisika yang keberadaannya bersifat hakiki (ma'nāwìyah) yang tidak membutuhkan pembuktian secara empiris. ${ }^{70}$ Pengetahuan yang sesungguhnya adalah pengetahuan metafisika yang bersifat ketuhanan, sedangkan pengetahuan positif itu diperlukan untuk mendukung kesempurnaan ilmu pengetahuan metafisika yang hakiki.

Klasifikasi yang dibuat Nursi ini terdapat kesamaan dengan klasifikasi yang dibuat oleh al-Ghazālī, yang menglasifikasikan ilmu menjadi dua, yaitu ilmu syar'ìyah (agama) dan ilmu 'aqlìyah (akal). Ilmu agama meliputi: ilmu tauhid, kenabian, akhirat, al-Qur'ān, alHadīts, ijma', qiyas, ilmu tentang ibadah, dan ilmu akhlaq. Sedangkan ilmu akal mencakup: ilmu kedokteran, geometri, astronomi, musik, ilmu fisika, dan sejenisnya. Kemudian al-Ghazālī membagi hukum mencari ilmu pengetahuan yang bersandar dari akal menjadi tiga 
bagian: terpuji, tercela, dan diperbolehkan. Secara umum hukum mencari ilmu pengetahuan akal dalam kategori terpuji adalah hukumnya fard al-kifäyah. Jadi tidak ada hukum fard al-'ayn dalam mencari ilmu akal. ${ }^{71}$

Dari sini nampaknya al-Ghazālī juga masih memrioritaskan ilmu-ilmu agama di atas ilmu-ilmu umum begitu juga dengan Nursi, akan tetapi dalam masalah ilmu-ilmu positif atau umum, Nursi tidak lagi menyinggung hukum memelajarinya apakah fard al-kifāyahatau bukan seperti yang dikatakan al-Ghazālī, tetapi Nursi lebih menekankan pentingnya memelajari ilmu pengetahuan umum untuk melengkapi dan sebagai sarana untuk lebih memahami ilmuilmu agama.

Meskipun pengetahuan sesungguhnya adalah pengetahuan metafisika (hakiki), bukan berarti pengetahuan selain itu tidak penting atau bahkan tidak dibutuhkan. Nursi berpendapat bahwa ilmu pengetahuan modern perlu dipelajari, karena manusia akan mendapatkan kesejahteraan dan kesempurnaan hidupnya jika dia menguasai ilmu-ilmu modern juga.

Nursi mengungkapkan alasan ilmu agama harus dikombinasikan dengan ilmu pengetahuan modern:

Hikmah penyatuan ilmu pengetahuan modern dengan ilmu pengetahuan agama adalah untuk menyelamatkan pemikiran akal dari kesesatan, karena memancarnya cahaya hati adalah dengan ilmuilmu agama, sedangkan bersinarnya akal adalah dengan ilmu-ilmu modern. Maka menggabungkan keduanya akan memunculkan suatu hakikat" ${ }^{72}$

Jadi ilmu pengetahuan modern harus diintegrasikan dengan ilmu pengetahuan agama, supaya ilmu pengetahuan modern tidak hampa dan menjadikan seseorang melalaikan Tuhannya.

Menurut Nursi, semangat al-Qur'àn adalah mengajarkan agar manusia memelajari dan memanfaatkan alam untuk kesejahteraan dunia menuju akhiratnya. Pemanfaatan ini membutuhkan ilmu pengetahun modern sesuai dengan perkembangan zamannya. Seluruh pengetahuan yang berkembang dari zaman ke zaman, semangat besarnya telah ada dalam kandungan al-Qur'ān. ${ }^{73}$

Akan tetapi tidak semua ilmu modern itu baik atau disarankan. 
Bahkan ada beberapa ilmu pengetahuan modern yang perlu diwaspadai. Ilmu falsafat Barat misalnya, menurut Nursi perlu dipilah dan dicermati. Nursi menolak falsafat materialisme ${ }^{74}$ (falsafah alMädīyah) dan Empirisme ${ }^{75}$ (falsafah al-Ṭabìyah) yang merupakan sisi negatif ilmu pengetahuan modern. Falsafat ini dinilai sesat, karena akan menjerumuskan dan melalaikan manusia dari Tuhannya. ${ }^{76}$ Falsafat ini memahami alam hanya pada eksistensinya sendiri, dan tidak memercayai adanya kekuatan sebenarnya yang ada di balik alam, yakni Tuhan. ${ }^{77}$

Nursi hanya menerima falsafat yang sejalan dengan penguatan iman kepada Allah. Bahkan dia menyatakan pentingnya falsafat semacam ini, karena selaras dan akan menjelaskan ajaran al-Qur'ān. ${ }^{78}$ Falsafat seperti ini akan mengarahkan pada arah keharmonisan yang ideal.

Nursi menganggap bahwa setiap ilmu pengetahuan ataupun sains dan teknologi adalah netral dan bebas nilai pada asalnya. Kebenaran bisa datang dari mana saja, karena sebenarnya kebenaran tersebut telah tercakup dalam naungan universalitas Islam dan al-Qur'ān. Sehingga ilmu pengetahuan umum yang menyimpang dari Islam perlu diislamkan supaya sesuai dengan nilai-nilai universal Islam.

Sedikit berbeda dari Nursi, Osman Bakar mengatakan bahwa ilmu pengetahuan atau sains tidaklah bebas nilai dan juga tidak sepenuhnya universal. Setiap sains yang dikembangkan dalam sebuah ruang historis dan kultural memiliki dimensi universal yang juga diapresiasi oleh semua budaya serta dimensi partikular yang diarahkan oleh berbagai prioritas kultural yang inheren dalam nilai budaya yang bersangkutan. Setiap peradaban memilih mewarisi berbagai tradisi ilmiah peradaban-peradaban lainnya hanya pada elemen-elemen yang dipandang sesuai dengan pandangan dunianya dan penting dari sudut pandang sistem nilainya, sehingga terdapat diskontinuitas atau keterputusan yang mencolok antara sains Islam tradisional dengan sains Barat modern. Sains Barat modern dituntun oleh sebuah paradigma dunia baru, yang dengan sadar memisahkan diri dari jalan keagamaan dan falsafi sains Islam, sedangkan sains Islam dibentuk dan diwarnai oleh keyakinan dan sistem nilai Islam. ${ }^{79}$

Nursi hidup ketika ilmu pengetahuan positif ${ }^{80}$ (umum) dan 
teknologi yang datang dari Barat sedang mendapatkan surganya, dan gerakan reformasi pendidikan sudah dimulai pada masa kesultanan Abdul Hamid. ${ }^{81}$ Kondisi pendidikan sebelum itu berjalan dengan silabus dan kurikulum yang tidak pernah diubah semenjak abad ke15 , bahkan infrastruktur bangunan madrasah pun hampir roboh, dan tidak tersedianya fasilitas-fasilitas yang mendukung berkembangnya para siswa. ${ }^{82}$

Kelompok Tanzimat yang dilanjutkan golongan Turki Muda semakin gencar melakukan reformasi dalam segala bidang, tak terkecuali bidang pendidikan ikut digarapnya. Reformasi pendidikan dilakukan dengan mengganti madrasah-madrasah dan seluruh lembaga ahli telah digantikan dengan sistem-sistem pendidikan dan hukum ala Barat.

Vahide mencatat bahwa Nursi sempat mengusulkan beberapa rancangan untuk reformasi pendidikan kepada Sultan Abdul Hamid, usulan tersebut kemudian dimuat dalam Şark Kürdistan Gazetesi (Surat Kabar Kurdistan dan Timur) yang tertanggal 19 November $1908 .{ }^{83}$ Dalam usulan reformasi pendidikan tersebut, Nursi mengulasnya dalam karya yang berjudul Munāzarāt yang terdapat dalam kitab Saiqal al-Islām:

Untuk menanggulanginya: harus dibangun Universitas Medresetuz Zehra (sebagai saudara kembar Universitas al-Azhar), dan dibangun di tiga tempat, yaitu di Bitlis, di kota Van, dan di kota Driyarbakr, untuk dijadikan contoh yang harus ditiru, dan juga sebagai penyemangat serta perangsang. Sekolah-sekolah ini harus diperkenalkan dengan istilah yang sudah akrab, yaitu madrasah. Harus mengintegrasikan ilmu-ilmu modern sekaligus dengan ilmuilmu agama, serta menggunakan tiga bahasa dalam pengajarannya, bahasa Arab yang statusnya wajib, bahasa Kurdi hukumnya boleh, dan bahasa Turki statusnya adalah perlu. Para sarjana Kurdi yang dipercaya oleh bangsa Kurdi maupun Turki harus dipilih sebagai guru, sebagaimana juga mereka yang menguasai bahasa daerah, dan bahwa para guru itu perlu memerhitungkan kapasitas serta tingkat budaya masyarakat yang akan mereka layani. Madrasah-madrasah ini harus setaraf dengan sekolah-sekolah resmi lainnya, dan seperti mereka, ujian-ujian madrasah tersebut harus diakui. Dan juga, 
revitalisasi sejumlah madrasah lain akan menjadi cara yang efektif untuk menyelamatkan masa depan masyarakat baik secara material, moral, maupun spiritual. Dengan begitu, akan terbangun landasan pendidikan yang berkembang". ${ }^{84}$

Inti dari usulan reformasi pendidikan Nursi adalah penyatuan tiga aspek. Pertama adalah penyatuan tiga cabang utama lembaga pendidikan, madrese atau sekolah agama tradisional, mekteb atau sekolah sekular baru, dan tekke atau lembaga-lembaga Sufi, yang semuanya disatukan ke dalam sistem pendidikan dan disiplin ilmu yang mereka wakili. Bidang kedua adalah restrukturisasi pendidikan madrasah secara menyeluruh. Bidang ketiga adalah menyangkut para pengajarnya, yang membimbing publik secara umum. ${ }^{85}$ Meskipun Nursi menganggap peran yang akan dimainkan Medresetuz Zehra tersebut sangat vital untuk menyelamatkan masa depan Kurdistan pada awalnya dan persatuan kekaisaran, akan tetapi prinsip-prinsip umum yang dia kemukakan tersebut dapat diterapkan pada semua lembaga pendidikan.

Agaknya apa yang diungkapkan Nursi ini selaras dengan pemikiran Muhammad 'Abduh (1845-1905 M.) Dalam sebuah kesempatan 'Abduh juga menyatakan perlunya mengadakan pembaruan lembaga pendidikan Islam pada saat itu. 'Abduh memasukkan pengetahuan modern ke dalam kurikulum al-Azhar. ${ }^{86}$

Menurutnya, umat Islam mengalami problem otentisitas Islam yang dianutnya. Hal ini menyebabkan umat Islam mengalami kemunduran. Islam yang dianut umat bukanlah Islam yang sebenarnya. Untuk meraih kejayaannya kembali harus ada kesadaran untuk kembali kepada Islam sejati, di samping juga melakukan gerakan pembaruan dan modernisasi dalam berbagai hal termasuk pendidikan.

Sikap jumud (statis) yang menghiasi alam pikiran dan prilaku umat Islam sebelumnya merupakan biang kemunduran yang menyebabkan mereka tidak dinamis, berhenti berpikir dan berusaha. $\mathrm{Hal}$ ini sangat bertentangan dengan prinsip-prinsip Islam yang mengandung unsur-unsur gerak yang dinamis dan relevan untuk sepanjang masa. Islam tidak bertentangan dengan ilmu pengetahuan modern. Kemajuan Islam sebagaimana yang pernah dicapai pada 
masa-masa keemasannya adalah karena mementingkan pengetahun, yang berarti memberikan porsi yang besar bagi akal untuk memahami ayat-ayat Tuhan. ${ }^{87}$ Karenanya perlu memasukkan kurikulum baru mengenai ilmu pengetahuan modern ke dalam madrasah dan alAzhar, sebagai salah satu syarat awal mencapai kemajuan tersebut.

'Abduh mengritik sistem pengajaran yang berlaku di lembaga pendidikan Islam, madrasah maupun al-Azhar, yang dianggapnya beku, dogmatis, dan membelenggu pemikiran. Dia berpendapat bahwa pendidikan dan sains Barat modern adalah kunci kemakmuran dan kejayaan Eropa. Dia memandang perlu digalakkan usaha-usaha pengembangan sistem pendidikan baru ke seluruh pelosok Mesir dan negera-negara Islam yang berdekatan agar menjadi negara besar dan kuat.

Pikiran senada juga dilontarkan oleh Fazlur Rahman (1919), yang kontribusi besarnya adalah upaya melakukan rekonstruksi sistemik terhadap epistemologi keilmuan, baik dengan memerbaiki cara berpikirnya, sistem pendidikannya ataupun corak keberagamaannya ${ }^{8}$ Menurut Rahman hanya dengan cara inilah suatu kebangkitan kembali umat Islam dapat diwujudkan.

\section{Nasionalisme Islami}

Proses modernisasi Turki adalah proses perdebatan panjang yang terjadi di antara para pembaharu Turki tentang bagaimana menyikapi ide-ide Barat, ajaran Islam, dan budaya lokal Turki. Hubungan agama dan negara menjadi sorotan penting: apakah Islam masih perlu dibangkitkan dalam bentuk negara Islam, atau ditolak sama sekali, ataukah hanya diambil nilai-nilai Islamnya untuk diintegrasikan dalam bernegara ${ }^{89}$ dengan bentuk nasionalisme.

Merespon isu nasionalisme yang waktu itu gencar dikumandangkan, dan dimotori di bawah komando Mustafa Kemal Attaturk, Nursi memunyai persepsi dan konsepsi tersendiri dalam memandang nasionalisme waktu itu.

Ketika Nursi menafsirkan surat al-Hujurāt/49: 13, "Hai manusia, Sesungguhnya kami menciptakan kamu dari seorang laki-laki dan seorang perempuan dan menjadikan kamu berbangsa-bangsa dan bersuku-suku supaya kamu saling kenal-mengenal. Sesungguhnya 
orang yang paling mulia di antara kamu di sisi Allah ialah orang yang paling taqwa di antara kamu. Sesungguhnya Allah Maha mengetahui lagi Maha Mengenal”.

Allah telah menciptakan kita bersuku-suku, bangsa-bangsa, dan kaum-kaum supaya kita saling mengenal, dan memahami hubungan sosial untuk saling menguatkan satu sama lain. Allah tidak menjadikan kalian bersuku-suku dan berbangsa-bangsa untuk saling bermusuhan. ${ }^{90}$

Berawal dari ayat ini juga, kemudian Nursi menyinggung tentang nasionalisme yang pada waktu itu sedang gencar-gencarnya diterapkan di Turki. Nursi melihat bahwa ide Nasionalisme (al-qawmìyah) dapat mengancam persatuan umat Islam. Nasionalisme adalah ide yang dipropagandakan Barat untuk memecah-belah persatuan umat Islam. Dengan nasionalisme, umat Islam akan saling memerebutkan daerah teritorial masing-masing sehingga akan muncul permusuhan dan peperangan di antara mereka, yang ujungnya akan memuluskan jalan bagi para imperialis Barat untuk menjajahnya. ${ }^{91}$

Nursi membedakan nasionalisme menjadi dua, yaitu nasionalisme negatif (al-qawmīyah al-salbiyah), dan nasionalisme positif (alqawmìah al-ijäbiyah). Nasionalisme negatif adalah suatu bentuk nasionalisme yang akan menimbulkan permusuhan dan perpecahan, karena akan terjadi perebutan kekuasaan dan pengaruh dari masingmasing wilayah akibat dari sensitifitas nasionalismenya. Oleh karena itu, Allah melarang rasa kesukuan jahiliah (al-așabìyah al-jähilīyah). Allah memerintahkan untuk meninggalkan rasa kesukuan untuk menuju kepada persaudaraan umat dengan dasar taqwa. Dalam alQur'ān surat al-Fatḥ/48: 26 disebutkan: "Ketika orang-orang kafir menanamkan dalam hati mereka kesombongan (yaitu) kesombongan jahiliah lalu Allah menurunkan ketenangan kepada Rasul-Nya, dan kepada orang-orang mu'min dan Allah mewajibkan kepada mereka kalimat-taqwa dan adalah mereka berhak dengan kalimat taawa itu dan patut memilikinya. Dan adalah Allah Maha Mengetahui segala sesuatu”.

Sejarah telah memerlihatkan dengan jelas tentang bahaya nasionalisme yang negatif ini. Dinasti Umayyah yang telah mengadopsi sebagian sistem nasionalisme ini telah menyebabkan beberapa unsur 
masyarakat marah dan akibatnya terjadi sejumlah pemberontakan. Begitu juga ketika ide nasionalisme modern dikembangkan di Eropa, sehingga terjadi pertentangan antara Perancis dan Jerman, sehingga kemudian terjadi Perang Dunia yang sangat mengerikan. ${ }^{92}$

Bentuk nasionalisme yang kedua adalah nasionalisme Positif (al-qawmiyah al-ijäbìyah). Nasionalisme ini tumbuh dari dalam kehidupan sosial bermasyarakat yang dapat menumbuhkan perasaan saling membantu. Munculnya kelompok-kelompok yang memerkuat kaumnya dalam masyarakat Muslim adalah dengan tujuan supaya kelompok yang kuat tersebut dapat membantu kelompok yang lemah. Kelompok ini tidak bertujuan untuk memisahkan diri dari kelompok besar masyarakat Muslim, akan tetapi justru membantu memerkuatnya. Nasionalisme yang dikembang masyarakat Muslim adalah untuk membentengi al-Qur'ān dan memerkuat Islam. Nasionalisme seperti ini selaras dengan apa yang ada dalam surat alMāidah/5: 54, "Maka kelak Allah akan mendatangkan suatu kaum yang Allah mencintai mereka dan mereka pun mencintaiNya, yang bersikap lemah lembut terhadap orang yang mu'min, yang bersikap keras terhadap orang-orang kafir, yang berjihad di jalan Allah". ${ }^{93}$

Dari penjelasan ini dapat dipahami bahwa, konsep nasionalisme menurut Nursi adalah nasionalisme yang tidak tercerabut dari akar Islamnya. Nasionalisme yang bertujuan untuk memerkuat persatuan dan memercepat kemajuan Islam. Nasionalisme yang bernafaskan al-Qur'ān. Nasionalisme masing-masing kelompok yang berada di bawah satu payung Islam dan iman, yang terlepas dari batas teritorial. Nasionalisme yang mirip dengan konsep negara federal atau negara dengan otonomi khusus.

Nasionalisme yang digalakkan oleh Mustafa Kemal Attaturk semakin kebablasan. Praktik nasionalisme yang dilakukan justru tercerabut dari akar budayanya dan mengarah pada Westernisasi yang sekular. Banyak kebijakannya justru menghilangkan tradisi penduduk Turki setempat, seperti pelarangan memakai pakaian adat ataupun pakaian keagamaan dan diganti dengan pakaian ala Eropa. Akan tetapi di sisi lain, dia juga kebablasan dalam meletakkan nasionalisme tersebut, seperti adzan dan iqamah yang kemudian diganti dengan menggunakan bahasa Turki. Jadi kebijakan-kebijakannya cenderung 
memunyai standar ganda.

Merespon nasionalismeyang kebablasan ini, Nursi menanggapinya dalam al-Maktūbāt pada surat kedua puluh sembilan bagian akhir. Nursi mengatakan bahwa alasan orang-orang yang berusaha mengubah simbol-simbol Islam ini mendasarkan atas apa yang terjadi di Barat, ketika orang-orang Islam yang ada di London dan wilayah lainnya, mereka mengumandangkan adzan dan iqamah dengan bahasa mereka sendiri, sedangkan dunia Muslim tidak menentang apa yang mereka lakukan. Tetapi kemudian Nursi menjawabnya,

Untuk wilayah-wilayah di mana orang-orang kafir hidup secara dominan disebut dengan 'daerah kekuasaan perang', dan terdapat beberapa hal yang secara agama diperbolehkan di 'daerah kekuasaan perang' tetapi tidak diperbolehkan di dunia Muslim. Kedua, agama Kristen dominan di Barat. Karena Barat bukanlah lingkungan yang secara normal mengilhami dan menanamkan makna istilah-istilah Islam dan kandungan kata-kata atau frase sakral, maka Muslim Barat mungkin merasa enggan untuk mengorbankan bahasa asli mereka untuk makna-makna sakral. Tetapi seluruh lingkungan di dunia Muslim mengajarkan umat Islam makna singkat dari katakata dan frase sakral tersebut. Semua wacana tentang tradisi-tradisi Islam, seluruh sejarah Islam, dan terutama sekali simbol atau tanda dan pilar-pilar Islam, selalu dan terus-menerus memasukkan makna singkat frasa-frasa sakral itu kepada orang-orang mu'min. Di samping masjid dan institusi pembelajaran keagamaan, bahkan batu nisan dan tulisan pada batu nisan di negara ini mengingatkan, seperti seorang guru bagi orang-orang mu'min tentang makna sakral simbol-simbol Islam"94.

Tanggapan Nursi bahwa, nasionalisme yang digalakkan dengan justru menghilangkan simbol-simbol Islam adalah tindakan yang salah dan kebablasan. Nursi menolak upaya nasionalisme yang sedang digalakkan waktu itu, karena meskipun disuarakan untuk memerkuat Islam, akan tetapi menurut praktik yang ada ternnyata nasionalisme yang diterapkan adalah nasionalisme yang sekular. Oleh karena itu, Nursi hanya menerima nasionalisme berlandaskan Islam yang sesungguhnya.

Nursi, dalam tulisan-tulisannya, secara mendasar bertentangan 
dengan pemikiran banyak pemikir Islam pada masa itu. Para pemikir kontemporer seperti, Hassan al-Bannā, Sayyid Quṭb, dan 'Allāmah al-Mawdūdī, masih menyokong kebangkitan kembali Islam sebagai sarana politik, bukan hanya Islam sebagai iman. Akan tetapi setelah perang Dunia I, Nursi tidak lagi tertarik untuk mengusung Islam sebagai alat politik untuk sarana memelihara Islam. ${ }^{95}$ Nursi tidak lagi mengidealkan kebangkitan Islam sebagai suatu bentuk negara, akan tetapi yang lebih penting adalah Islam perlu ditegakkan dan diintegrasikan nilai-nilainya dalam bernegara maupun segala aspek kehidupannya.

Pendapat Nursi ini berbeda dari apa yang diperjuangkan oleh gerakan Islam fundamentalis ${ }^{96}$ sebelumnya yaitu Ikhwān al-Muslimīn yang dirumuskan oleh Hasan al-Bannā. Dia merumuskan ideologi Ikhwān al-Muslimīn yang menekankan kemampuan Islam sebagai ideologi yang total dan komprehensif.

Tujuan politik Ikhwān al-Muslimīn adalah pembentukan kekhalifahan yang terdiri dari negara-negara Muslimin yang merdeka dan berdaulat. Kekhalifahan ini harus didasarkan sepenuhnya pada ajaran al-Qur'ān. Tujuan kekhalifahan adalah untuk mencapai keadilan sosial dan menjamin kesempatan yang memadai bagi semua individu Muslim. ${ }^{97}$ Setelah meninggalnya Hasan al-Bannā, perjuangan Ikhwān al-Muslimīn diteruskan oleh Sayyid Quṭb.

Salah satu doktrin sentral dalam fundamentalisme Quṭb yang selanjutnya yang dianut oleh Ikhwān al-Muslimīn adalah konsep tentang "jahiliah modern". ${ }^{98}$ Konsep jahiliah modern itu sendiri pertama kali dikembangkan pada 1939 oleh Abū al-A'lā al-Mawdūdī, tokoh terkemuka fundamentalis lainnya dan pendiri organisasi Jamā'ah al-Islāmì, di anak Benua India. Al-Mawdūdī merupakan pemikir Muslim pertama yang dengan tegas mengutuk modernitas dan ketidaksesuaiannya dan bahayanya terhadap Islam. ${ }^{99}$ Kemudian Quṭb mengelaborasi lebih jauh konsep ini, dan menjadi tokoh fundamentalis pertama yang sampai pada pengutukan menyeluruh terhadap modernitas, ketidakcocokannya dengan Islam, dan bahaya yang dimunculkannya terhadap Islam.

Menurut Sayyid Quṭb, untuk menumpas jahiliah modern, masyarakat Muslim harus melakukan perubahan fundamental dan 
radikal, bermula dari dasar-dasar kepercayaan, moral dan etikanya. Dominasi atas manusia harus dikembalikan semata-mata kepada Allah, tegasnya kepada Islam yang merupakan suatu sistem holistik. Serangan menyeluruh dan sistematis, tepatnya jihad harus dilancarkan terhadap modernitas. Tujuan akhir jihad adalah membangun kembali "kekuasaan Tuhan" di muka bumi, di mana syari'ah memegang supremasi tertinggi. Syari'ah dalam arti lebih luas yang tidak hanya mencakup sistem hukum saja, akan tetapi mencakup segala aspek dalam kehidupan manusia. ${ }^{100}$

Berbeda dari apa yang diperjuangkan para golongan fundamentalis, Nursi tidak lagi tertarik pada upaya kebangkitan Islam melalui terbentuknya negara Islam, akan tetapi perlunya diintegrasikan nilai-nilai Islam dalam kehidupan bernegara. Selaras dengan apa yang digagas oleh Nursi adalah pendapat Gamal alBannā, tidak lain adalah adik kandung dari Hasan al-Bannā, peletak dasar gerakan Ikhwān al-Muslimīn. Gamal al-Bannā meyakini bahwa negara Islam (dawlah Islāmī̄h) memang pernah tegak berdiri,tetapi itu hanya terjadi pada zaman Nabi Muhammad dan Khulafä’ alRāsyidīn; setelah itu, pemerintahan Islam dikendalikan oleh pribadipribadi yang despotis atau lalim dan dipacu oleh panasnya syahwat kekuasaan semata. Karena itu, pembentukan pemerintahan Islam pasca Nabi dan Khulafä al-Rāsyidin oleh gerakan-gerakan Islam kontemporer terasa utopia, bahkan banyak yang berakhir dengan kegagalan. Gamal al-Bannā mengidealkan sebuah sosok pemerintahan yang lebih membumikan Islam dalam membangun kemaslahatan umat, karena yang terpenting adalah penerapan nilai-nilai Islam dan pendaratan kebajikan secara universal (al-Mașäliḥ al-'̄Ammah). ${ }^{101}$

\section{Perempuan dan Persamaan Hak}

Nasionalisme yang mengarah pada sekularisme adalah praktik yang kemudian diterapkan oleh Mustafa Kemal waktu itu, meskipun pada konsep awalnya, Kemal mengidealkan bahwa nasionalisme yang diusung adalah nasionalisme sekular yang mengintegrasikan nilai-nilai agama ke dalam birokrasi pemerintahan. Akan tetapi pada tataran praksis, bisa dianggap bahwa nasionalisme diterapkan pada bentuk yang sinonim dengan Westernisasi sekular, dan bahkan tidak 
memerhitungkan aspek agama.

Nasionalisme yang dijalankan tidak terkecuali pada bidang pemerintahan, hukum, pendidikan, ekonomi, maupun budaya. Akan tetapi masalah relasi hubungan laki-laki dan perempuan -yang pada waktu itu masih dianggap isu yang baru- juga tidak luput dari perhatian. Momentumnya adalah ketika diberlakukannya UU Perdata sebagai ganti dari peraturan-peraturan Syariat dan mengadopsi UU Perdata Swiss, yang kemudian memberlakukan sekularisasi upacara pernikahan, pengadopsian prinsip monogami, laki-laki dan perempuan memunyai hak yang sama dalam menuntut talak, pembolehan pernikahan beda agama, orang tua laki-laki dan perempuan memunyai hak yang sama atas anak, dan pemberian hak warisan yang sama antara pria dan wanita.

Perubahan tersebut kemudian memengaruhi relasi kehidupan antara laki-laki dan perempuan dalam masyarakat. Hingga pada akhirnya, jika dulu perempuan bebas mengenakan jilbab, maka pada perkembangan selanjutnya, perempuan yang berjilbab semakin dipersempit ruang geraknya mulai dari lembaga-lembaga pemerintahan hingga pada lembaga pendidikan, ${ }^{102}$ yang akhirnya mengakibatkan timbulnya pergaulan tidak sehat di kalangan para generasi muda.

Nursi merasa prihatin pada kondisi yang seperti ini, hingga ia memberikan perhatian khusus pada masalah perempuan dan permasalahan jilbab (hijäb) $)^{103}$ yang sedang terjadi waktu itu. Keprihatinan tersebut diwujudkan dalam bentuk sebuah tulisan yang berjudul Risālah al-Hijāb, karya ini merupakan bagian dari Risālah al-Nür yang terdapat pada kitab al-Lama'àt kedua puluh empat, dan ditulis ketika ia diasingkan di Asbarithah tahun 1934. Dan karena Risālah al-Hijāb ini juga beliau akhirnya dituntut dan dipenjara di Eskisehir dengan tuduhan menyebarkan semangat keagamaan melalui penyebaran Risālah al-Hijāb. ${ }^{104}$

Risālah al-Hijāb ini berisi tentang bantahan Nursi terhadap persepsi peradaban modern yang mengatakan bahwa hijāb (jilbab) mengakibatkan ruang gerak seorang perempuan menjadi terbatas. ${ }^{105}$ Nursi memaparkan argumentasinya yang terinspirasi oleh surat alAhzāb/33: 59, "Hai Nabi, Katakanlah kepada isteri-isterimu, anak- 
anak perempuanmu dan isteri-isteri orang mu'min: Hendaklah mereka mengulurkan jilbabnya ke seluruh tubuh mereka. Yang demikian itu supaya mereka lebih mudah untuk dikenal. Karena itu mereka tidak diganggu, dan Allah adalah Maha Pengampun lagi Maha Penyayang”.

Argumentasi Nursi, hijāb adalah fitrah bagi perempuan, karena perempuan pada dasarnya diciptakan dalam fitrahnya yang lemah lembut dan penuh kasih sayang. Mereka membutuhkan seorang pelindung laki-laki yang dapat melindungi mereka dan anak-anaknya. Perempuan memiliki kecenderungan fitrah untuk membuat dirinya dicintai, dan tidak ditolak secara kasar. Nursi menolak peradaban modern yang mencampakkan jilbab, karena telah berlawanan dengan fitrah. ${ }^{106}$

Dengan berjilbab, perempuan justru akan terlindungi dari kerendahan dan direndahkan, terbebas dari perbudakan secara maknawi, serta terselamatkan dari kemalangan jika memang jilbab difungsikan sebagaimana mestinya dan dijadikan sebagai media kontrol bagi perempuan dari berbuat kotor dan hina.

Menurut Nursi, penyebab kerusakan yang terjadi tersebut adalah karena kondisi pada waktu itu, di mana pembaruan pendidikan yang diterapkan pada waktu era reformasi Tanzimat yang diteruskan oleh gerakan Turki Muda, adalah sistem pendidikan sekular yang mengesampingkan nilai-nilai Islam di dalamnya, bahkan pelajaran agama mulai ditinggalkan pada tahun 1924 di masa Kemal. Nursi memaparkan,

Kemudian aku mencari sebab-sebab kerusakan tersebut. Akupun mengetahui ada beberapa lembaga rahasia yang berusaha menyesatkan dan merusak para pemuda dengan cara menyediakan berbagai sarana maksiat serta menjerumuskan mereka kepada kemaksiatan dan kesesatan guna merusak tatanan masyarakat Islam dan menyerang agama Islam. Aku juga merasakan dan mengetahui adanya berbagai lembaga yang bekerja secara efektif untuk mendorong para perempuan yang lalai agar terjerumus ke dalam dosa dan kesalahan. Menurutku, hal ini merupakan pukulan keras terhadap umat Islam. Aku jelaskan secara gamblang wahai para anak perempuanku yang masi h remaja, sesungguhnya solusi ampuh untuk menyelamatkan perempuan dari kerusakan dunia dan akhirat, serta sarana satu-satunya untuk menjaga ta- 
biat mulia yang menjadi fitrah mereka dari kerusakan adalah mendidik mereka dengan pendidikan agama dalam Islam. ${ }^{107}$

Pada waktu itu, sistem pendidikan sekolah diletakkan di bawah pengawasan Kementerian Pendidikan. Madrasah-madrasah ditutup dan digantikan dengan sekolah-sekolah sekular. Universitasuniversitas mulai membuka Fakultas Teologi. Bahkan selanjutnya pendidikan agama ditiadakan di sekolah-sekolah pada tahun $1930 .{ }^{108}$ Sistem pendidikan sekular yang diterapkan mengakibatkan rusaknya tatanan masyarakat Islam, tak terkecuali bagi perempuan. Pendidikan sekular yang diterapkan justru merusak moral generasi perempuan, dan menjauhkan mereka dari fitrahnya yang penuh kasih sayang. Yang dihasilkan adalah generasi perempuan yang rusak akhlaknya dan lalai akan fitrahnya.

Nursi menyadari pentingnya aplikasi nilai-nilai Islam supaya diterapkan dalam kehidupan perempuan sehari-hari, agar dipraktikkan dalam tindak laku akhlak kehidupan. Islam adalah agama yang ramah, syari'atnya bukan berarti memenjarakan perempuan supaya terbelenggu, akan tetapi justru akan memerdekakan perempuan dari berbagai penjajahan dan kegelapan perilaku kotor masa lalu.

Dalam penafsirannya, Nursi menempatkan perempuan pada tempat yang mulia, karena menurut Nursi perempuan adalah makhluk yang memunyai fitrah mulia, di mana kasih sayang dan cinta sebagai fitrah yang memenuhi mereka, sehingga menjadikan mereka kuat dalam beragama karena keberagamaan mereka dipenuhi dengan cinta. Nursi menulis,

Hadìts yang berbunyi "Kalian harus mengikuti agama para perempuan tua," ${ }^{109}$ mendorong kita untuk mengikuti agama mereka. Artinya, iman yang kuat di akhir zaman nanti, akan dimiliki oleh para perempuan tua. Salah satu dari empat pilar Risälah Nür adalah kasih sayang. ${ }^{110}$ Karena para perempuan merupakan pahlawan kasih sayang, maka orang yang paling penakut di antara mereka sekalipun akan rela mengorbankan jiwa untuk menyelamatkan anaknya. ${ }^{111}$

Nursi juga mengakui adanya hak dan kebebasan bagi perempuan untuk menentukan pilihannya, bahkan dalam menentukan laki-laki pilihannya untuk dijadikan suami, dan hak untuk bekerja maupun kebebasan beraktifitas bagi mereka. Dan Nursi menolak segala 
macam kejahatan, ataupun penindasan yang terjadi dan dialamatkan pada para perempuan,

Wahai saudara-saudara perempuanku. Secara khusus kukatakan hal ini kepada kalian. Bekerjalah mencari nafkah dengan tangan sendiri seperti para perempuan desa. Lalu berusahalah hidup hemat dan qana'ah, dua sifat yang tertanam dalam fitrah kalian. Hal ini lebih baik daripada kalian merusak diri kalian sendiri karena tuntutan hidup dengan tunduk pada dominasi seorang suami yang jahat, berperilaku buruk, dan kebarat-baratan. ${ }^{112}$

Dari beberapa kutipan ini dapat ditangkap bahwa Nursi sudah memunyai wacana persamaan hak dalam perspektif gender. ${ }^{113}$ Nursi menganjurkan perempuan untuk bekerja dan menolak segala macam penidasan serta penyimpangan dalam relasi antara perempuan dan laki-laki. Peran perempuan didedikasikan untuk menguatkan eksistensinya dalam masyarakat, kebudayaan, ataupun pendidikan. ${ }^{114}$ Jadi relasi antara perempuan dan laki-laki adalah hubungan yang saling menyempurnakan dan saling menutupi kekurangan masingmasing untuk menuju keharmonisan dalam berumahtangga yang didasarkan pada nilai-nilai Islam.

Ada beragam pendapat di kalangan ulama dalam menanggapi masalah hijäb ini. Para ulama salaf berpendapat bahwa seluruh tubuh wanita adalah aurat, termasuk wajah dan kedua telapak tangan. AlAlūsī mengatakan bahwa surat al-Aḥzāb/33: 59 yang menerangkan tentang perintah untuk mengulurkan Jilbab atas tubuh mereka "yudnina 'alayhinna min jaläbībibinna" maka kata "alaybinna" yang dimaksud adalah ke seluruh tubuh mereka. ${ }^{115}$

Senada dengan al-Alūsī, al-Biqāī dalam tafsirnya Nażm al-Durar fì Tanāsub al-Āy wa al-Suwar menyebutkan beberapa pendapat tentang makna jilbab. Antara lain, baju yang longgar atau kerudung penutup kepala wanita, atau pakaian yang menutupi baju dan kerudung yang dipakainya, atau semua pakaian yang menutupi badan wanita. Semua pendapat ini menurut al-Biqāī dapat merupakan makna kata tersebut. Jika yang dimaksud dengan jilbab adalah baju, maka ia adalah pakaian yang menutupi tangan dan kaki. Jika yang dimaksud adalah kerudung, maka perintah mengulurkannya adalah menutup wajah dan lehernya. Dan jika yang dimaksud adalah pakaian yang menutupi 
badan, maka perintah mengulurkannya adalah membuatnya longgar sehingga menutupi semua badan dan pakaian. ${ }^{116}$

Meskipun pada awal tujuan diturunkannya ayat ini adalah untuk membedakan antara perempuan merdeka dan perempuan sahaya, akan tetapi menurut pendapat ulama salaf kandungan ayat tersebut tetap berlaku sampai sekarang dan untuk masa datang.

Sementara para cendekiawan kontemporer seperti Qāsim Amīn dalam bukunya Tahrir al-Mar'ah, menyatakan bahwa tidak ada satu ketetapan agama (nas dari syari'at) yang mewajibkan pakaian khusus seperti hijāb atau jilbab bagi perempuan, sebagaimana yang dikenal selama ini dalam masyarakat Islam. Dia mengatakan bahwa pakaian tersebut adalah adat kebiasaan yang lahir akibat pergaulan masyarakat Mesir (Islam) dengan bangsa-bangsa lain, yang mereka anggap baik dan kemudian menirunya lalu menilainya sebagai doktrin agama. Dia juga berpendapat bahwa al-Qurān membolehkan perempuan untuk menampakkan sebagian dari anggota tubuhnya di hadapan orang-orang yang bukan mahramnya, akan tetapi al-Qur'ān tidak menentukan bagian mana dari anggota tubuh itu yang boleh dibuka. ${ }^{117}$

Pendapat Muhammad Syahrūr bisa dikatakan meneruskan pendapat Qāsim Amīn. Syahrūr dalam bukunya al-Kitāb wa alQur'ān: Qiräah Mu'ạsirah menjelaskan bahwa pakaian tertutup yang kini dinamai hijāb (jilbab) bukanlah suatu kewajiban agama, akan tetapi hal tersebut merupakan suatu bentuk pakaian yang dituntut oleh kehidupan masyarakat dan lingkungan, sehingga dapat berubah dengan perubahan masyarakat dan lingkungan yang berbeda. Ayat tentang jilbab di atas yang memerintahkan Nabi untuk menyampaikan kepada istri, anak-anak perempuan beliau, serta wanita Muslimah agar mengulurkan jilbab mereka adalah dalam konteks untuk membedakan antara wanita merdeka dari para sahaya. Hal ini merupakan suatu tindakan pengaturan untuk menanggulangi situasi khusus yang terjadi di Madinah waktu itu. ${ }^{118}$

Tetapi ada juga pendapat yang dengan terang-terang mengatakan bahwa pakaian wanita yang tertutup merupakan suatu bentuk perbudakan pria terhadap wanita, seperti apa yang ditulis oleh Nawāl al-Sa'dawī dan Hibah Ra'ūf 'Izzah. Mereka mengatakan bahwa hijāb yang bersifat material maupun immaterial telah menutup keterlibatan 
wanita dalam kehidupan politik, agama, akhlak, dan bidang-bidang lainnya. Lebih tegas lagi, ada yang mengatakan bahwa "saya menolak hijāb (pakaian tertutup), karena menutup ataupun telanjang, keduanya menjadikan wanita sebagai jasad semata. Ketika saya menutup badan saya, maka itu mengandung arti bahwa saya adalah fitnah (penggoda/ perayu) dan akan merayu pria bila membuka pakaian. Ini salah, karena saya adalah akal dan bukan jasad yang mengandung syahwat atau rayuan." 119 Pendapat ini terdengar lebih berani dan berbeda dari dua pendapat di atas.

Pendapat Nursi seakan mencari jalan tengah. Ia tetap mewajibkan perempuan untuk memakai hijāb atau jilbab yang menjadi fitrah mereka, akan tetapi dengan adanya jilbab tersebut tidak berarti akan menjadi penghalang bagi perempuan untuk bersosialisasi dalam kehidupan sosialnya, sehingga Nursi tidak melarang wanita untuk beraktifitas di luar maupun bekerja. Nursi juga menolak segala macam penindasan terhadap perempuan dalam kehidupan berumah tangga. Nursi memaknai hubungan perempuan dengan laki-laki sebagai suatu hubungan yang saling menyempurnakan kekurangan masing-masing pihak untuk dapat membentuk keharmonisan dalam kehidupan.

\section{Simpulan}

Keterpengaruhan pemikiran dan penafsiran Nursi dalam karyanya Risālah al-Nūr terhadap Turki dapat kita lihat dari tiga hal, yaitu mengenai perkembangan ilmu pengetahuan dan teknologi, kemudian dalam masalah hubungan agama dan negara, dan juga dalam masalah relasi antara perempuan dan laki-laki.

Nursi tidak hanya melihat ayat-ayat al-Qur'ān dari sisi tekstualnya yang terbatas saja, akan tetapi Nursi juga mengontekstualisasikan ayat-ayat tersebut ke dalam kehidupan masa kini dan menggunakan pendekatan rasional dalam menjelaskannya, serta menyandarkan pendekatan-pendekatan rasionalisme berpikirnya pada keyakinan atas kebenaran teks-teks agama tersebut.

Melihat sifat penafsiran kontekstual yang dilakukan Nursi, bukan berarti merupakan salah satu bentuk dari politisasi ayat-ayat al-Qur'ān. Namun Nursi berupaya untuk mengontekstualisasikan 
ayat-ayat al-Qur'ān dan mendialogkan dengan kehidupan sosial pada masanya, supaya ayat-ayat al-Qur'ān tidak hanya dipahami sebagai sebuah dokumen tekstual yang mati dan kehilangan signifikansinya dengan perilaku konkrit masyarakat. Karena letak kekuatan al-Qur'ān adalah justru pada kekuatan ayat-ayatnya yang universal dan telah diproyeksikan untuk bisa menjadi bagian penting dalam proses kritik sosial dalam kehidupan masyarakatnya.

\section{Catatan Akhir}

1 Modernisasi adalah proses sikap dan mentalitas warga masyarakat untuk bisa hidup sesuai dengan masa kini, Lihat Kamus Besar Bahasa Indonesia (Jakarta: Balai Pustaka, 1988), 589.

2 Quraish Shihab, Membumikan Al-Qur'ün : Fungsi Dan Peran Wahyu Dalam Kehidupan Masyarakat (Bandung: Mizan), 87.

3 Ihsan Kasim Salih, Said Nursi; Pemikir \& Sufi Besar Abad 20, Penerjemah Nabilah Lubis (Jakarta: PT Raja Grafindo Persada, 2003), 8, dan Şükran Vahide, Biografi Intelektual Bediuzzaman Said Nursi ; Transformasi Dinasti 'Utsmünì Menjadi Republik Turki, Penerjemah: Sugeng Haryanto, Sunoko (Jakarta; Anatolia, 2007), 3.

${ }^{4}$ Şükran Vahide, Biografi Intelektual Bediuzzaman Said Nursi, xii.

5 Said Nursi, Risülah An-Nür; Sinar Yang Mengungkap Sang Cahaya, Penerjemah Sugeng Hariyanto, Sukono Mukidi, MoRudi Atmoko (Jakarta; Kencana, 2003), XIII

6 Vahide, Biografi Intelektual Bediuzzaman Said Nursi, xiv.

7 Şükran Vahide, Biografi Intelektual Bediuzzaman Said Nursi, xvii.

8 Şükran Vahide, Biografi Intelektual Bediuzzaman Said Nursi ; Transformasi Dinasti Usmani Menjadi Republik Turki (Jakarta; Anatolia, 2007).

9 Ihsan Kasim Salih, Said Nursi Pemikir \& Sufi Besar Abad 20 (Jakarta; Kencana, 2003).

${ }^{10}$ Muhammad Adlan, "Metode Penafsiran Al-Qur'ān Said Nursi Dalam Risūlah An-Nūr," (Skripsi S1 Fakultas Ushuluddin dan Filsafat, Universitas Islam Negeri, Syarif Hidayatullah Jakarta, 2004).

${ }^{11}$ Iis Ishak Sholih, "Nasionalisme Islam; Pemikiran Politik Said Nursi," (Skripsi S1 Fakultas Ushuluddin dan Filsafat, Universitas Islam Negeri Syarif Hidayatullah Jakarta, 2007).

${ }^{12}$ Hasbi Sen, "Prinsip-prinsip Politik Islam Menurut Bediuzzaman Said Nursi," (Tesis Program Pascasarjana, IAIN Raden Fatah Palembang, 2007).

${ }^{13}$ Afriyantoni, "Prinsip-prinsip Pendidikan Akhlak Generasi Muda Menurut Bediuzzaman Said Nursi," (Tesis Program Pascasarjana, IAIN Raden Fatah Palembang, Jurusan Ilmu Pendidikan Islam Konsentrasi Pemikiran Pendidikan Islam, 2007).

${ }^{14}$ Salih, Said Nursi, 8 dan Vahide, Bediuzzaman, 3. 
${ }^{15}$ Moh. Asror Yusuf, Persinggungan Islam dan Barat; Studi Pandangan Badiuzzaman Said Nursi (Kediri, STAIN Kediri Press, 2009), 23.

${ }^{16}$ Wara' menurut bahasa ialah menjauhi dosa, lemah, lunak hati, dan penakut. Sedangkan menurut istilah, para ulama' mempunyai sejumlah pengertian masing-masing tentang wara', Ibnu al-Qayyim al-Jawzìyah menarik kesimpulan bahwa wara' adalah membersihkan kotoran hati, sebagaimana air membersihkan kotoran dan najis pakaian. Tim Penulis UIN Syarif Hidayatullah, Ensiklopedi Tasawuf(Bandung: Penerbit Angkasa, 2008), 1441.

${ }_{17}$ Salih, Said Nursi, 9-10, Lihat juga Vahide, Bediuzzaman, 9-10

${ }^{18}$ Salih, Said Nursi, 11-12.

${ }^{19}$ Salih, Said Nursi, 13.

${ }^{20}$ H.A. Fuad Said, Hakikat Tarikat Naqsyabandiah (Jakarta: PT. Pustaka al-Husna Baru, 2007), 21.

${ }^{21}$ Yusuf, Persinggungan Islam dan Barat, 30.

${ }^{22}$ Vahide, Bediuzzaman, 30

${ }^{23}$ Badìuzzamūn berarti keajaiban zaman, Nursi menggunakan gelar ini bukan dalam bentuk kesombongan, akan tetapi dia menggunakan nama itu sebagai bentuk untuk menunjukkan karunia ilahi, dan dia mengatakan bahwa gelar Bediuzzaman lebih merupakan gelar maknawi bagi Risalah al-Nur. Lihat Badī’ Al-Zamūn Sà̄ìd Al-Nūrsi, Sìrah Dzūtīyah. Penerjemah Ihsūn Qūsim Al-Sūlihi (Qūhirah: Sözler, 2004), 64.

${ }^{24}$ Vahide, Bediuzzaman, 31-33, lihat juga Salih, Said Nursi, 14.

${ }^{25}$ Yusuf, Persinggungan Islam dan Barat, 23.

${ }^{26}$ Mu'allifu Rasüìli al-Nūr, Badì' al-Zamūn Sà̃̀d al-Nürsī; Lamhüt Min Hayūtihi Wa 'Ütsūrihi (İstanbul: Sözler Neşriyat), 46.

${ }^{27}$ Afriyantoni, "Prinsip-Prinsip Pendidikan Akhlak Generasi Muda Menurut Bediuzzaman Said Nursi, ”(S2 Program Pascasarjana, Jurusan Ilmu Pendidikan Islam, Konsentrasi Pemikiran Pendidikan Islam, IAIN Raden Fatah Palembang, 2007), 91-94, diakses dari http://www.risalahnur.com/?page_id=34, tgl. 27 Oktober 2009.

${ }^{28} 40$ bahasa tersebut, di antaranya adalah: Bahasa India, Hungaria, Indonesia, Itali, Jepang, Kazakstan, Kirgistan, Korea, Bahasa Kurdi, Masedonia, Melayu, Ottoman, Persia, Portugis, Rumania, Rusia, Sansekerta, Spanyol, Swedia, Filipina, Tatar, Thailan, , Uigur, Urdu, Usbekistan, Afganistan, Albania, Arab, bahasa Azarbaijan, Banglades, Bosnia, Bulgaria, Cina, Denmark, Belanda, Inggris, Perancis, Georgia, Jerman, Yunani, Gujarat. The World is Reading Risale-i Nur (Istanbul; Sözler Publication).

${ }^{29}$ Yusuf, Persinggungan Islam dan Barat, 18.

${ }^{30}$ Nasution, Pembaruan Dalam Islam, 126.

${ }^{31}$ Abdul Sani, Lintasan Sejarah Pemikiran; Perkembangan Modern Dalam Islam (Jakarta, PT Raja Grafindo Persada, 1998), 110.

32 Sani, Lintasan Sejarah Pemikiran, 111.

${ }^{33}$ Erik J. Zürcher, Sejarah Modern Turki. Penerjemah: Karsidi Diningrat R. (Jakarta: Gramedia Pustaka Utama, 2003), 165. 
${ }^{34}$ Sani, Lintasan Sejarah Pemikiran, 113.

${ }^{35}$ Dalam konstitusi 1876, tercantum bahwa agama kerajaan 'Utsmūnī adalah Islam. Nasution, Pembaruan Dalam Islam, 133.

${ }^{36}$ Sani, Lintasan Sejarah Pemikiran, 115.

37 Zürcher, Sejarah Modern Turki, 165.

38 Zürcher, Sejarah Modern Turki, 119.

39 Zürcher, Sejarah Modern Turki, 138.

${ }^{40}$ Zürcher, Sejarah Modern Turki, 250.

${ }^{41}$ Sekularisasi dalam Kamus Besar Bahasa Indonesia adalah hal yang membawa ke arah kecintaan kehidupan duniawi sehingga norma-norma tidak perlu didasarkan pada ajaran agama, Sekularisme adalah faham yang memisahkan kehidupan duniawi bernegara dengan agama, Kamus Besar Bahasa Indonesia (Jakarta: Balai Pustaka, 1988), 797.

42 Sani, Lintasan Sejarah Pemikiran, 116.

${ }^{43}$ Zürcher, Sejarah Modern Turki, 162.

${ }^{44}$ Sani, Lintasan Sejarah Pemikiran, 118-119.

${ }^{45}$ Nasution, Pembaruan Dalam Islam, 137.

${ }^{46}$ Sani, Lintasan Sejarah Pemikiran, 120.

${ }^{47}$ Zürcher, Sejarah Modern Turki, 164.

${ }^{48}$ Ziya Gökalp, The Principles Of Turkism (Leiden: E.J. Brill, 1968).

${ }^{49}$ Zürcher, Sejarah Modern Turki, 166.

50 Sani, Lintasan Sejarah Pemikiran, 119-121.

${ }^{51}$ Lihat Sani, Lintasan Sejarah Pemikiran, 122-123.

${ }^{52}$ Zürcher, Sejarah Modern Turki, 162.

${ }^{53}$ Sani, Lintasan Sejarah Pemikiran, 123.

54 Zürcher, Sejarah Modern Turki, 306.

55 Toprak, Islam dan Perkembangan Politik di Turki, 70.

56 Toprak, Islam dan Perkembangan Politik di Turki, 153.

${ }^{57}$ Nasution, Pembaruan Dalam Islam, 153.

${ }^{58}$ Era Modern yang di asumsikan penulis adalah, Turki pada masa-masa setelah gerakan modernisasi yang digalakkan di Turki, yaitu periode setelah Republik Turki dengan Nasionalisme sekularnya di bawah kekuasaan otoriter Mustafa Kemal Attaturk.

${ }^{59}$ Lihat Sani, Lintasan Sejarah Pemikiran, 131.

${ }^{60}$ Nasution, Pembaruan Dalam Islam, 154.

${ }^{61}$ Lihat Maryam Jameelah, Islam dan Modernitas. Penerjemah A. Jainuri dan Syafiq A. Mughni (Surabaya: Usaha Nasional, t.t.), 267. Lihat juga Sani, Lintasan Sejarah Pemikiran, 132.

${ }^{62}$ Toprak, Islam dan Perkembangan Politik di Turki, 157

${ }^{63}$ Baca, Sirin Tekeli, ed., Women In Modern Turkish Society (London: Zed Books, 1995), 14.

${ }^{64} \mathrm{ht} \mathrm{tp}: / /$ i n ternational. okezone.com/index.ph p / ReadStory/2008/02/10/18/82331/, diakses pada 5 maret 2010.

${ }^{65}$ Lihat Sani, Lintasan Sejarah Pemikiran, 133. 
${ }^{66}$ Şükran Vahide, Biografi Intelektual Bediuzzaman Said Nursi ; Transformasi Dinasti Usmani Menjadi Republik Turki, Penerjemah Sugeng Haryanto, Sunoko (Jakarta; Anatolia, 2007), xvii.

${ }^{67}$ Bediuzzaman Said Nursi, Dari Balik Lembaran Suci Penerjemah Sugeng Hariyanto (Jakarta: Siraja, 2003), 18-19.

${ }^{68}$ Yusron Razak, ed., Sosiologi Sebuah Pengantar; Tinjauan Pemikiran Sosiologi Perspektif Islam (Tangerang: Laboratorium Sosiologi Agama, 2003), 26.

${ }^{69}$ Dalam Saiqal Al-Islüm, Nursi menggunakan istilah al-'Ulūm al-Müdìyah, sedangkan dalam Isyūrūt al-Ijüz, Nursi menggunakan istilah Funun untuk menyebut istilah ilmu pengetahuan positif (umum). Lihat Nūrsi, Saiqal AlIslūm; Muhūkamūt 'Aqlīyah, 33. Badī' Al-Zamūn Sa'ìd Al-Nūrsi, Isyūrūt al-Ijūz (Qūhirah: Sözler, 2004), h.173.

${ }^{70}$ Nūrsi, Saiqal Al-Islüm; Muhükamūt 'Aqlìyah, 33.

${ }^{71}$ Baca Osman Bakar, Hierarki Ilmu; Membangun Rangka Pikir Islamisasi Ilmu. Penerjemah Purwanto (Bandung: Mizan, 1997), 231-242.

${ }^{72}$ Badī' Al-Zamūn Sa’īd al-Nūrsi, Saiqal Al-Islūm; Munūzarūt. Penerjemah Ihsūn Qūsim Al-Sūlihi (Qūhirah: Sözler, 2004), 428.

${ }^{73}$ Badī' Al-Zamūn Sa'īd Al-Nūrsi, Isyūrūt al-Ijūz (Qūhirah: Sözler, 2004), 180. Sebagai contoh bulatnya bumi, yang merupakan permasalahan mendasar yang ada dalam ilmu Geografi, telah diterangkan dalam al-Qur'ān. Lihat Nūrsi, Saiqal Al-Islūm; Muhükamūt 'Aqlīyah, 24.

${ }^{74}$ Filsafat Materialis adalah filsafat yang menganggap bahwa materi adalah satusatunya hal yang nyata. Materi adalah hal yang terdalam dan bereksistensi atas kekuatannya sendiri, dan tidak memerlukan suatu prinsip yang lain untuk menerangkan eksistensinya sendiri. Louis O. Kattsoff, Pengantar Filsafat. Penerjemah Soejono Soemargono (Yogyakarta: Tiara Wacana Yogya, 1996), 123.

${ }^{75}$ Filsafat Empirisme adalah filsafat yang mendasarkan pengetahuan berdasarkan pengalaman dan juga fakta yang dialaminya secara pribadi. Kattsoff, Pengantar Filsafat, 122.

${ }^{76}$ Badī' Al-Zamūn Sa'īd Al-Nūrsi, Al-Malūhiq; Mulhaq AmīrdūgPenerjemah Ihsūn Qūsim Al-Sūlihi (Qūhirah: Sözler, 2004), 286. Lihat juga Badī' Al-Zamūn Sa’ìd Al-Nūrsi, Al-Matsnūwì al-'Arabì al-Nūrì (Qūhirah: Sözler, 2004), 329.

${ }^{77}$ Nursi menjelaskan perbedaan pemahaman terhadap ego manusia dan alam, sisi pertama menggunakan dasar pemahaman kenabian dan sisi kedua berdasarkan atas pemahaman filsafat (materialisme). Sisi pertama memandang eksistensi ego bukan eksistensi yang abadi dan sesungguhnya, eksistensi bersifat harfìyyah, bukan substansi, wujudnya bersifat asesoris, sehingga tergantung Tuhan yang menggerakkan dan mewujudkannya. Sementara sisi kedua memahaminya bahwa eksistensi ego adalah Ismī, pengertian formal, bukan harfïyah, dan dalam wujud asli, bukan asesoris, serta menganggap sebagai hakikat yang permanen, sehingga pemahaman dengan menggunakan sisi kedua mengakibatkan munculnya kaum imperialis kafir dan aliran pemikiran materialisme atheis yang menolak segala hal yang metafisik seperti Tuhan. Badiuzzaman Said Nursi, $\mathrm{Al}$ - 
Matsnawi An-Nuri; Menyibak Misteri Keesaan Ilahi. Penerjemah Fauzy Bahreisy (Jakarta: Anatolia,t.t.), 369.

${ }^{78}$ Nūrsi, Al-Malūhiq; Mulhaq Amìrdügh, 286-287.

${ }^{79}$ Osman Bakar, Tauhid \& Sains; Perspektif Islam tentang Agama \& Sains. Penerjemah Yuliani Lupito dan M.S. Nasrullah (Bandung: Pustaka Hidayah, 2008), 37-38.

${ }^{80} \mathrm{Ilmu}$ pengetahuan positif (positive science) adalah buah dari faham positivisme yang dipelopori oleh Agust Comte (1798-1857), kemudian diteruskan oleh John Stuart Mill (1806-1873) dan Herbert Spencer (1820-1903). Positivisme adalah kelanjutan dari faham Empirisme yang berkembang pada abad ke-17 dengan tokohnya antara lain Thomas Hobbes (1588-1679) dan Jhon Locke (1632-1704). Baik empirisme maupun positivisme, sama-sama mendasarkan pengetahuan berdasarkan pengalaman dan fakta. Hanya saja perbedaannya adalah, positivisme membatasi pengetahuan pada sesuatu yang objektif saja, sementara empirisme menerima juga pengetahuan yang bersumber dari intuisi dan pengalaman subjektif. Moh. Asror Yusuf, Persinggungan Islam dan Barat; Studi Pandangan Badiuzzaman Said Nursi (Kediri, STAIN Kediri Press, 2009), 117. Lihat Kattsoff, Pengantar Filsafat, 119.

${ }^{81}$ Vahide, Biografi Intelektual Bediuzzaman Said Nursi, 42.

82 Vahide, Biografi Intelektual Bediuzzaman Said Nursi, 51.

${ }^{83}$ Vahide, Biografi Intelektual Bediuzzaman Said Nursi, 50.

${ }^{84}$ Nūrsi, Saiqal Al-Islüm; Munüzarūt, 427-429

${ }^{85}$ Vahide, Biografi Intelektual Bediuzzaman Said Nursi, 52.

${ }^{86}$ Harun Nasution, Pembaruan Dalam Islam; Sejarah Pemikiran Dan Gerakan (Jakarta: Bulan Bintang, 1975), 57-61.

${ }^{87}$ Lihat Nasution, Pembaruan Dalam Islam, 61-64. Akal digunakan untuk memikirkan sebab musabab dan juga segala akibat, sementara hati digunakan untuk merasakan pergolakan yang terjadi dalam jiwa dan diri. Maka ilmu yang sehat akan membimbing perasaan, sementara perasaan yang sejahtera akan jadi pembantu utama bagi ilmu. Tegasnya, agama yang sempurna merupakan gabungan antara ilmu dan perasaan, akal dengan hati, pembuktian dan kepatuhan, serta pemikiran dan kepercayaan. Persoalan dunia ini akan berakhir dengan terpadunya ilmu dengan agama menurut al-Qur'ān dan Sunnah. Lihat Syekh Moh. 'Abduh, Ilmu dan Peradaban; Menurut Islam dan Kristen. Penerjemah Mahyuddin Syaf \& A. Bakar Usman, (Bandung: Diponegoro, 1992), 168-169.

${ }^{88}$ Lihat Fazlur Rahman, Islam Dan Modernitas; Tentang Transformasi Intelektual. Penerjemah Ahsin Muhammad (Bandung: Pustaka, 1995), 184.

${ }^{89}$ Erik J. Zürcher, Sejarah Modern Turki. Penerjemah Karsidi Diningrat R. (Jakarta: Gramedia Pustaka Utama, 2003), h.161.

${ }_{90}$ Pada umumnya ayat ini ditafsirkan oleh para ulama klasik dalam konteks sosial kemasyarakatan, untuk memaknai bagaimana adanya perbedaan sukusuku dan kabilah adalah justru untuk membuat saling mengenal satu dan yang lainnya untuk membangun ukhuwwah. Ulama klasik dalam menafsirkan ayat 
ini, belum sampai pada suatu konsep tertentu dalam wujud formulasinya, tapi masih dalam tataran konsep normatif. Lihat Mahmūd al-Alūsī, Rūh alMàūnì fì Tafsìri al-Qur'ün al-Azìm wa al-Sabì al-Matsūnī, vol. 19 (Beirut: Dūr al-Kutub al-'Ilmīyah, 1994), 289. Lihat juga Ibn Katsìr, Tafsīr al-Qur'ūn al'Azīm, vol. 7 (t.tp.: Dūru Tayyibah li al-Natsri wa al-Tauzì, 1999), 386. Sama juga dengan apa yang dikatakan al-Sūbūnī, lihat Muhammad 'Alī al-Sūbūnī, Safwat al-Tafūsīr, vol. 3 (Beirut: Dūr al-Fikr, 2001), 219. Berbeda dengan Said Nursi yang berangkat dari ayat ini juga, kemudian Nursi sampai pada konsep Nasionalisme Islami yang diterangkan dalam karyanya al-Maktūbüt.

${ }^{91}$ Badī' Al-Zamūn Sàìd Al-Nūrsi, Al-Maktūbūt. Penerjemah Ihsūn Qūsim AlShūlihi (Qūhirah: Sözler, 2004), 414.

${ }^{92}$ Nūrsi, Al-Maktūbūt, 414.

${ }^{93}$ Nūrsi, Al-Maktūbūt, 415-416.

${ }^{94}$ Said Nursi, Menjawab Yang Tak Terjawab, Menjelaskan Yang Tak Terjelaskan. Penerjemah Sugeng Hariyanto dkk. (Jakarta: Raja Grafindo Persada, 2003), 574-575.

${ }^{95}$ Lihat Vahide, Biografi Intelektual Bediuzzaman Said Nursi, xiv. Lihat juga Azyumardi Azra, Pergolakan Politik Islam; Dari Fundamentalisme, Modernisme, Hingga Post-Modernisme (Jakarta : Paramadina, 1996), 118.

${ }^{96}$ Fundamentalis adalah istilah yang relatif baru dalam kamus peristilahan Islam. Istilah fundamentalisme Islam di kalangan Barat mulai populer berbarengan dengan terjadinya Revolusi Islam Iran pada 1979, yang memunculkan kekuatan Muslim Syi'ah radikal dan fanatik yang siap mati melawan the great satan, Amerika Serikat. Setelah Revolusi Islam Iran, istilah fundamentalisme Islam digunakan untuk menggeneralisasi berbagai gerakan Islam yang muncul dalam gelombang yang sering disebut sebagai "kebangkitan Islam". Azyumardi Azra, Pergolakan Politik Islam; Dari Fundamentalisme, Modernisme, Hingga PostModernisme (Jakarta : Paramadina, 1996), 107.

${ }^{97}$ Azyumardi Azra, Pergolakan Politik Islam; Dari Fundamentalisme, Modernisme, Hingga Post-Modernisme (Jakarta : Paramadina, 1996), 117, Lihat juga Antony Black, Pemikiran Politik Islam; Dari Masa Nabi Hingga Masa Kini. Penerjemah Abdullah Ali dan Mariana Ariestyawati (Jakarta: Serambi, 2006), 573.

${ }^{98}$ Jahilīyah modern adalah situasi di mana nilai-nilai fundamental yang diturunkan Tuhan kepada manusia diganti dengan nilai-nilai artifisial atau palsu yang berdasarkan hawa nafsu duniawi. Jahilīyah modern merajalela di muka bumi ketika Islam kehilangan kepemimpinan atas dunia, sementara pada pihak lain, Eropa mencapai kejayaannya.

${ }^{99}$ Azra, Pergolakan Politik Islam, 118

100 Azra, Pergolakan Politik Islam, 120.

101 Baca Gamal al-Banna, Relasi Agama \& Negara. Penerjemah Tim MataAir Publishing (Jakarta: MataAir Publishing, 2006), 331- 361.

102 Larangan berjilbab bagi para mahasiswi di lembaga pendidikan ditetapkan pada tahun 1997, meskipun larangan tersebut akhirnya dapat diamandeman atas persetujuan Parlemen pada tanggal 10 Februari 2008. 
103 Hijūb yang berati tutup, dimaksudkan Nursi adalah makna hijab secara lebih luas, tidak hanya dimaknai sebagai sebuah bentuk jilbab atau kerudung, akan tetapi keharusan perempuan untuk menutup auratnya, hal ini diindikasikan dengan ulasan Nursi dalam risalah ini yang mengulas dan menerangkan bahayanya perempuan yang membuka auratnya, sehingga dari situ akan menjadi sumber terjadinya malapetaka dan dekadensi moral.

104 Lihat Ihsan Kasim Salih, Said Nursi; Pemikir \& Sufi Besar Abad 20, Penerjemah Nabilah Lubis (Jakarta: PT Raja Grafindo Persada, 2003), 65.

105 Lihat Badī’ Al-Zamūn Sa’īd Al-Nūrsi, Al-Lama’ūt, Penerjemah Ihsūn Qūsim Al-Sūlihi (Qūhirah: Sözler, 2004), 300.

106 Said Nursi, Menikmati Takdir Langit. Penerjemah: Fauzy Bahreisy, Joko Prayitno (Jakarta: Raja Grafindo Persada, 2003), 368.

107 Nursi, Menikmati Takdir Langit, 379. Lihat juga Nursi, Tuntunan Bagi Perempuan, 30.

108 Lihat Nasution, Pembaruan Dalam Islam, 152.

109 Hadis riwayat al-Dailūmī, dari hadis Ibnu 'Umar yang terdapat dalam alDurar al-Mantsūrīyah karya al-Suyūtī. Lihat juga Majd al-Dīn Ibnu Atsīr, Jùmi' al-Usūlfì Ahūdìtsi al-Rasūl, vol. 1 (t.tt.: Maktabah al-Halwūnī, t.t.), 292.

110 Tiga pilar Risūlah al-Nūr yang lainnya adalah berfikir yang dilandasi keimanan pada Allah (tafakkur), ketidak berdayaan di hadapan Allah ('ajz), dan kefakiran di hadapan Allah (faqr).

111 Nursi, Tuntunan Bagi Perempuan, 27.

112 Nursi, Menikmati Takdir Langit, 23. Lihat juga Nursi, Tuntunan Bagi Perempuan, 29.

113 Gender adalah suatu konsep kultural yang berupaya membuat perbedaan (distinctions) dalam hal peran, perilaku, mentalitas, dan karakteristik emosional antara laki-laki dan perempuan yang berkembang di masyarakat. Lihat Asriati Jamil dan Amany Lubis, Pengantar Kajian Gender, (Jakarta: PSW UIN, 2003), 54.

114 Baca Amina Wadud, Quran Menurut Perempuan; Membaca Kembali Kitab Suci Dengan Semagat Keadilan. Penerjemah Abdullah Ali (Jakarta: Serambi, 2006), 180.

115 Mahmūd al-Alūsī, Rūh al-Ma'ūnī fì Tafsīiri al-Qur'ūn al-Azìm wa al-Sab'i alMatsūnī, vol. 11 (Beirut: Dūr al-Kutub al-'Ilmīyah, 1994), 263-265.

116 Ibrūhīm bin 'Umar al-Biqū'î, Naz\}m al-Durar fì Tanūsubi-al-A<yi wa alSuwar, vol. 15 (Kairo: Dūr al-Kutub al-Islūmī, 1992), 411-412.

117 M. Quraish Shihab, Jilbab Pakaian Wanita Muslimah; Pandangan Ulama Masa Lalu \& Cendekiawan Kontemporer (Jakarta: Lentera Hati, 2004), 166-167.

118 Muhammad Syahrūr, al-Kitūb wa al-Qur'ūn; Qira'ah Mu'ūsirah (Dimasyqa: al-Ahūlì li al-Tibū'ah wa al-Nasyri wa al-Tauzī', 1990), 614-615.

119 Shihab, Jilbab Pakaian Wanita Muslimah, 173. 